\title{
Free Trade, Immigrant Workers, and Employment Discrimination
}

\author{
Angela D. Morrison *
}

\section{INTRODUCTION}

Although Title VII of the Civil Rights Act of 1964 grants noncitizen workers a right to a workplace free from unlawful discrimination, noncitizen workers in the United States are vulnerable to unlawful discrimination because of gaps in enforcement ${ }^{1}$ and a narrative that noncitizen workers are less deserving of protection than citizen workers. ${ }^{2}$ This has led to under-enforcement of workplace protections and over-enforcement of immigration laws. ${ }^{3}$ As a result, noncitizen workers do not enjoy all of the workplace protections provided them in U.S. domestic law.

Anti-discrimination in employment provisions in Free Trade Agreements are an overlooked source of protection for noncitizen workers in the

\footnotetext{
* Associate Professor of Law, Texas A\&M University School of Law. I thank the participants in the SEALS new scholar program and the $11^{\text {th }}$ Annual Colloquium on Current Scholarship in Labor and Employment Law for their comments, including, Brad Areheart, Marcia McCormick, Nancy Levitt, Ruben Garcia, Ann McGinley, Rick Bales, Jedidiah Kroncke, and Maria Ontiveros. Thanks also to the faculty of Mizzou Law for hosting a presentation of this paper, and to Dennis Crouch, David Mitchell, Brook Gotberg, Jim Levin, Royce Barondes, Rigel Oliveri, Anne Alexander, and Rafael Gely for their comments and suggestions. The article also benefitted from the editors' comments and work, in particular, I appreciate the efforts of Nancy Musick and Chris Carey. Finally, I appreciate the generous research grant that the Texas A\&M University School of Law provided for this article. Any errors are my own.

1. See Angela D. Morrison, Executive Estoppel, Equitable Enforcement, and Exploited Immigrant Workers, 11 HARV. L. \& POL'Y REV. 295 (2017) [hereinafter Morrison, Executive Estoppel] (arguing that U.S. agencies' conflicting treatment of unauthorized workers leaves workers vulnerable to workplace exploitation); Leticia M. Saucedo, The Employer Preference for the Subservient Worker and the Making of the Brown Collar Workplace, 67 OHIO ST. L.J. 961, 969 (2006) (arguing that employers take advantage of under-enforcement of workplace laws and over-enforcement of immigration laws to cultivate an exploitable workforce); Angela D. Morrison, Duke-ing Out Pattern or Practice After Wal-Mart: The EEOC as Fist, 63 AM. U. L. REV. 87, 89-90 (2013) [hereinafter EEOC as Fist] (arguing that a consequence of narrowing the availability of pattern and practice Title VII suits to private litigants will result in less access to courts for victims of discrimination); and discussion infra regarding jurisdictional barriers U.S. agencies face in enforcing workplace protections transnationally.

2. See discussion infra Part I.B.

3. See discussion infra Part I.
} 
United States. Such provisions used creatively by workers and their advocates provide an opportunity to noncitizen workers to reinforce their rights under U.S. law by filling in gaps in enforcement, incentivizing U.S. agencies to enforce anti-discrimination laws, and creating a new narrative about noncitizen workers.

Both proponents and opponents of including labor provisions in trade agreements have focused on the impact the provisions will have on workers in developing countries. Proponents of linking trade to labor conditions make two main arguments - both of which focus attention on how the linkage will impact developing countries. First, some proponents assert that labor provisions in trade agreements will improve the conditions of workers in developing countries. ${ }^{4}$ Scholars and advocates who take this view have criticized free trade agreements for not doing enough to protect workers in developing countries. ${ }^{5}$

Second, some proponents of including worker rights in trade agreements argue that ensuring that the United States' trade partners comply

4. Marisa Anne Pagnattaro, Leveling the Playing Field: Labor Provisions in CAFTA, 29 FORDHAM InT'L L.J. 386, 386, 388 (2006) [hereinafter Pagnattaro, Leveling the Playing Field] ("When the United States enters into a free trade agreement ('FTA'), it has an opportunity to . . . improv[e] international core labor standards" and "[t]he promotion of fundamental labor rights . . . supports the right of international workers to enjoy the most basic threshold of workplace standards."); Marisa Anne Pagnattaro, The "Helping Hand" in Trade Agreements: An Analysis of and Proposal for Labor Provisions in U.S. Free Trade Agreements, 16 FLA. J. INT'L L. 845, 852-56 (2004) [hereinafter Pagnattaro, Helping Hand]; Justine Nolan \& Michael Posner, International Standards to Promote Labor Rights: The Role of the United States Government, 2000 COLUM. BuS. L. REV. 529, 531-32, 535-37, 541-42 (2000) (arguing that the United States should take the lead in making sure that men and women around the world have international workplace protections, in part, by linking trade with the United States' improved labor rights).

5. Deirdre Salsich, International Workers' Rights Enforced Through Free Trade Agreements: DR-CAFTA and the DOL's Case Against Guatemala, 25 N.Y. INT'L L. REv. 19, 26, 32-33 (2012) (critiquing recent trade agreements DR-CAFTA and NAALC as being ineffective in enforcing international labor norms in developing countries); Paulette L. Stenzel, The Pursuit of Equilibrium as the Eagle Meets the Condor: Supporting Sustainable Development Through Fair Trade, 49 AM. Bus. L.J. 557, 597-605 (2012) (critiquing NAFTA and its side labor agreement for failing to provide job benefits and worker protections for workers in Mexico); see Pagnattaro, Leveling the Playing Field, supra note 4 (critiquing the Dominican Republic-Central American Free Trade Agreement for three reasons: (1) free trade agreements only require countries to reasonably enforce their own labor laws and CAFTA countries' labor standards are not adequate; (2) CAFTA's dispute resolution procedures lack meaningful enforcement and are ineffective; and (3) there is no funding to ensure that CAFTA's cooperation and capacity building features will be effective); Edward Gresser, Labor and Environment in Trade Since NAFTA: Activists Have Achieved Less, and More, Than They Realize, 45 WAKE FoREST L. REV. 491, 502-20 (2010) (arguing that free trade agreements are less effective at enforcing labor rights than anticipated because more trade is covered by WTO provisions and that leads to coverage exceptions, and there is a mismatch in the justifications for the linkage between trade and labor rights). 
with similar labor standards to those in the United States protects American workers. ${ }^{6}$ They believe that lower standards and wages in other countries result in offshoring, drive down wages, and cost U.S. jobs. ${ }^{7}$ Thus, linking labor protections to trade will discourage companies from engaging in a race to the bottom because when developing countries allow companies to exploit their workforce, the countries will face trade sanctions.

Some opponents of including labor provisions in trade agreements argue that they result in trade barriers that harm workers in developing countries. ${ }^{8}$ They conclude that the provisions hurt workers in developing countries because those workers' labor provide their main competitive advantage in trade. ${ }^{9}$ Further, they maintain that fewer limits on trade would best serve workers in developing countries because trade promotes economic growth, naturally leading to improved labor conditions. ${ }^{10}$

This focus on the provisions as primarily protecting the rights of workers in other countries or as being enforceable only against developing countries leaves underexplored how the provisions benefit marginalized workers in the United States. An examination of the labor provisions in the most recent trade promotion authority and trade agreements demonstrates that U.S. workers, and in particular, noncitizen workers can benefit from the agreements. New provisions in free trade agreements that have enforceable anti-discrimination in employment and regulatory coherence requirements mean that U.S. agencies must enforce noncitizen workers' right to be free from employment discrimination, and that their failure to do so can result in trade sanctions or fines.

Moreover, the anti-discrimination provisions can serve as a frame for viewing noncitizens' workplace rights as human rights, and the United States' failure to enforce those rights as a rule of law failure. This reframing has the potential to change public opinion and pressure companies to change their behavior. Accordingly, free trade agreements can reinforce the rights of noncitizen workers in the United States in three ways: 1) they

6. See, e.g., Labor Advisory Comm. Trade Negotiations \& Trade Pol'y, Report on THE IMPACTS OF THE TRANS-PACIFIC PARTNERSHIP 6 (2015), https://ustr.gov/sites/default/files/Labor-Advisory-Committee-for-Trade-Negotiations-and-Trade-Policy.pdf [https://perma.cc/DLZ2Q5J7]; but see Andrew T. Guzman, Trade, Labor, Legitimacy, 91 CALIF. L. REV. 885, 887, 892 \& n.28 (2003) (citing the lack of empirical evidence for such claims and disagreeing with the view that low labor standards in one country harms workers in importing countries).

7. See, e.g., Labor AdVisory COMm. TRAde Negotiations \& TRAde Pol'y, supra note 6 , at 34, 38, 67-68 (describing perceived effects of the North American Free Trade Agreement and a race-to-the-bottom that it believes the Trans-Pacific Partnership will exacerbate).

8. Guzman, supra note 6 , at 886 \& n.6 (summarizing arguments against including labor sanctions in trade agreements and citing sources).

9. Id. at 886 \& n.7 (citing Jagdish Bhagwati, Afterword: The Question of Linkage, 96 AM. J. INT'L L. 126 (2002)).

10. Id. at 886 . 
fill in gaps in enforcement; 2) they incentivize enforcement; and 3) they reframe noncitizens' workplace rights as a rule of law issue.

This article argues that the anti-discrimination and regulatory cohesion provisions in free trade agreements are an overlooked opportunity for noncitizen workers to assert their workplace rights. Part I explains why noncitizen workers are more vulnerable to workplace abuses. In Part II, the article provides context by looking at the history of worker rights in trade promotion authority and in more recent free trade agreements, primarily the side labor agreement to the North American Free Trade Agreement, and the now defunct Trans Pacific Partnership. Part III argues that despite some potential challenges in enforcing the anti-discrimination provisions of free trade agreements, trade agreements that include anti-discrimination provisions and regulatory coherence measures will reinforce the rights of noncitizen workers.

\section{NONCITIZEN WORKERS ARE MORE VULNERABLE TO WORKPLACE}

\section{ABUSES}

Marley Weiss notes that "trade has caused markets for goods and services to interpenetrate among countries" and one effect has been the "movement, lawfully or unlawfully, of workers from one country to another." " And, in the United States, those transnational workers have become increasingly vulnerable to employer exploitation. ${ }^{12}$ Noncitizen workers have suffered pay discrimination based on national origin or gender, ${ }^{13}$ unsafe and dangerous working conditions because of their national

11. Marley S. Weiss, International Labor and Employment Law: From Periphery to Core, 25 ABA J. LAB. \& EMP. L. 487, 492 (2010). Most of the complaints brought against the United States under the North American Free Trade Agreement's labor side agreement involve Mexican workers alleging the United States has failed to enforce its laws with respect to protecting migrant workers, freedom of association, and safety and health standards. MARY JANE BOLLE, CONG. RESEARCH SERV., 97-861, NAFTA LABOR SIDE AGREEMENT: LESSONS FOR THE WORKER RIGHTS AND FAST-TRACK DEBATE 11 (2001).

12. Morrison, Executive Estoppel, supra note 1, at 297, 321; see also Saucedo, supra note 1, at 961-1021.

13. E.g., S. Poverty L. Ctr., Close to Slavery: Guestworker Programs in the United STATES 31-33 (2013) (summarizing cases in which temporary noncitizen workers experienced pay discrimination based on their national origin or gender); MARY BAUER \& MÓNICA RAMÍREZ, INJUSTICE ON OUR PLATES: IMMIGRANT WOMEN IN THE U.S. FOOD INDUSTRY 22-29 (2010) (summarizing interviews with noncitizen female workers in the agricultural and meat processing industry). 
origin, ${ }^{14}$ severe forms of sexual harassment-including sexual assault, ${ }^{15}$ and retaliation when they try to assert their rights. ${ }^{16}$

This despite that noncitizen workers enjoy the same protections under United States anti-discrimination laws as citizen workers. ${ }^{17}$ Title VII of the Civil Rights Act of 1964 prohibits employers from discriminating against noncitizen workers on the basis of sex, race, national origin, color, or religion. ${ }^{18}$ Those protections include prohibitions on subjecting an employee to a hostile work environment or harassment, disciplining an employee, terminating an employee, or subjecting an employee to different terms or conditions of employment. ${ }^{19}$ It similarly prohibits employers

14. See, e.g., EEOC v. Global Horizons, Inc. (Global Horizons II), 7 F. Supp. 3d 1053, 1059 65 (D. Haw. 2014) (granting summary judgment on the EEOC's claims that employer subjected noncitizen agricultural workers to a hostile work environment and different work conditions due to their national origin (Thai)); S. POVERTY L. CTR. \& ALA. APPLESEED CNT. FOR LAW \& JUSTICE, UNSAFE AT THese SPEEDS: Alabama's POUltry INDUSTRY AND ITS Disposable Workers 39-40 (2013) (describing results of surveys and interviews with workers in the Alabama poultry industry who reported receiving more dangerous and undesirable work assignments because of their national origin; workers also reported national origin harassment from coworkers).

15. See, e.g., Sasha Khokha, Silenced By Status, Farm Workers Face Rape, Sexual Abuse, NPR (Nov. 5, 2013, 5:26 PM), http://www.npr.org/2013/11/05/243219199/silenced-by-status-farm-workers-face-rape-sexual-abuse [https://perma.cc/2WC2-C3VJ] (describing sexual assault of female noncitizen agricultural workers who lacking status were afraid to report); Frontline: Rape on the Night Shift (PBS television broadcast June 22, 2015), https://www.pbs.org/video/frontline-rape-night-shift/ [https://perma.cc/56CC-TG3Y] (reporting on workplace sexual assaults of female noncitizen custodial workers); BAUER \& RAMÍREZ, supra note 13, at 41-47 (summarizing interviews with noncitizen female workers in the agricultural and meat processing industry).

16. See Global Horizons II, 7 F. Supp. at 1065-69 (granting summary judgment on the EEOC's claims that employer retaliated against noncitizen agricultural workers when they complained about discrimination under Title VII); see also Morrison, Executive Estoppel, supra note 1, at 297, 320-21, $321 \mathrm{nn} .177 \& 179$.

17. Morrison, Executive Estoppel, supra note 1, at 295-96, 302-20 (describing existing workplace protections for noncitizens under federal law and citing to Title VII of the Civil Rights Act of 1964, 42 U.S.C. $\S \S 2000 \mathrm{e}-1-2000 \mathrm{e}-15$ (2012)). Moreover, because interpretations of Title VII "apply with equal force in the context of age discrimination" and disability discrimination, noncitizen workers enjoy the same protections under the Age Discrimination in Employment Act and the Americans with Disabilities Act. Id. at 302 n.40 (first quoting Gross v. FBL Fin. Servs., Inc., 557 U.S. 167, 183 (2009) (Stevens, J., dissenting); then citing Carparts Distrib. Ctr. v. Auto. Wholesaler's Ass'n, 37 F.3d 12, 16 (1st Cir. 1994); and then quoting Krouse v. Am. Sterilizer, Co., 984 F. Supp. 891, 913 n.17 (W.D. Pa. 1996)). The only exception is that noncitizen workers do not receive the same protection from the Immigration Reform and Control Act's (IRCA) unfair immigration-related employment practices. 8 U.S.C. $\S 1324 b(2012)$.

18. 42 U.S.C. $\S \S 2000 \mathrm{e}-1-2000 \mathrm{e}-15$ (2012); Morrison, Executive Estoppel, supra note 1, at 296-97, 303-11 (arguing that federal anti-discrimination statutes extend protection to noncitizen workers and citing cases and legislative history); see also Keith Cunningham-Parmeter, Redefining the Rights of Undocumented Workers, 58 AM. U. L. REV. 1361 (2009) (arguing that the Supreme Court's decision in Hoffman Plastic Compounds, Inc. v. NLRB, 535 U.S. 137 (2002), should not impact unauthorized workers' right to remedy under Title VII).

19. 42 U.S.C. $\S 2000 \mathrm{e}-2$. An unauthorized employee would not be able to successfully assert a failure to hire claim. Morrison, Executive Estoppel, supra note 1, at 297, 310-11, $311 \mathrm{n} .101$ ("[T]he 
from retaliating against noncitizen employees who exercise their rights under Title VII. ${ }^{20}$ Other federal anti-discrimination statutes protect noncitizen employees from discrimination on the basis of disability or age. ${ }^{21}$

The reasons for noncitizen workers' vulnerability are complex and involve many factors. This article will discuss two. First, gaps in federal enforcement of anti-discrimination impact noncitizen workers, especially those who are unauthorized or hold a temporary or liminal immigration status. Second, there is little incentive for the federal government to make a concerted effort to enforce the rights of noncitizen workers, and that, combined with a view of immigrant workers as less deserving of protection than other workers, means there is little political will to put pressure on agencies to enforce anti-discrimination provisions when employers violate them.

\section{A. Gaps in Enforcement Increase Noncitizen Workers' Vulnerability}

There are three gaps in enforcement that leave noncitizen victims of discrimination unprotected. The first gap results from different agencies' conflicting treatment of noncitizen workers who experience discrimination on the job. The second results from the increasingly transnational nature of companies and their subcontractors; sometimes the United States lacks the jurisdiction to enforce workplace laws because the bad actors are outside the country. The third is lack of access to courts for victims of systemic discrimination as a result of recent Supreme Court decisions.

First, at least three different federal agencies may become involved when a noncitizen worker experiences employment discrimination: The Equal Employment Opportunity Commission (EEOC), the Department of Justice (DOJ), and the Department of Homeland Security (DHS). In some instances, one agency such as the EEOC may determine that the employee is a victim worthy of protection, but another agency such as DHS may

\footnotetext{
strong protections provided by federal employment law do not mean that employers must hire unauthorized workers in the first place. Indeed, to do so would violate [the Immigration Reform \& Control Act's] provisions. Rather, once someone who is unauthorized is already in the workplace, ... employers cannot subject their unauthorized employees to an abusive work environment.") (footnote omitted).

20. Morrison, Executive Estoppel, supra note 1, at 311-15 (arguing that Congress intended federal anti-retaliation provisions to apply to unauthorized immigrants).

21. See generally 42 U.S.C. $\S \S 12111-12117$ (2012) (Title I of the Americans with Disabilities Act of 1990); 29 U.S.C. $\S \S 621-634$ (2012) (Age Discrimination in Employment Act of 1967).
} 
decide to prosecute the worker. ${ }^{22}$ This has resulted in the under-enforcement of anti-discrimination laws because workers have been afraid to come forward to report. ${ }^{23}$

A case that noncitizen workers in a Tennessee cheese factory brought illustrates this gap. ${ }^{24}$ The employer hired the workers knowing they were not authorized to work in the United States and that the documents the workers presented were fake. ${ }^{25}$ After the workers stopped work because they said the employer subjected them to a discriminatory workplace and owed them wages, the employer called the local sheriff's office to have them arrested. ${ }^{26}$ The sheriff arrested them and turned them over to DHS. ${ }^{27}$

Eventually, the workers received a U nonimmigrant visa, a temporary visa for victims of crime. ${ }^{28}$ The visa requires that a law enforcement official certify that the noncitizen (1) suffered substantial physical or mental abuse because the noncitizen was the victim of a crime, (2) possesses information concerning the crime, (3) has been helpful, is being helpful, or is likely to be helpful in the investigation or prosecution of the crime, and (4) the crime violated the laws of the United States. ${ }^{29}$ DHS signed off on the U visa for the workers based on what happened to them at their workplace. ${ }^{30}$ Nonetheless, DOJ decided to prosecute the workers for using false

22. Morrison, Executive Estoppel, supra note 1, at 295-97, 316-22; Leticia M. Saucedo, Immigration Enforcement Versus Employment Law Enforcement: The Case for Integrated Protections in the Immigrant Workplace, 38 FoRDHAM URB. L.J. 303 (2010).

23. Morrison, Executive Estoppel, supra note 1, at 295-97, 320-21.

24. Montano-Perez v. Durrett Cheese Sales, Inc., 666 F. Supp. 2d 894 (M.D. Tenn. 2009).

25. United States v. Ramirez, 635 F.3d 249, 257, 260-61 (6th Cir. 2011) (affirming the conviction of the company's hiring agent for conspiracy to commit social security fraud, harboring unlawful immigrants, and perjury).

26. Montano-Perez, 666 F. Supp. $2 \mathrm{~d}$ at 898.

27. Id. at $898-99$.

28. Durrett Cheese Case, S. POVERTY L. CTR., https://www.splcenter.org/seeking-justice/casedocket/juana-montano-pérez-et-al-v-durrett-cheese-sales-inc [https://perma.cc/3LQK-RTWX] (last visited Oct. 3, 2018).

29. 8 U.S.C. $\S 1101(a)(15)(U)(i)(2012$ \& Supp. 2017). The Department of Labor, the EEOC, DHS, and DOJ are all defined as law enforcement agencies under the regulations. 8 C.F.R. $\S 214.14(a)(2)$ (2018). The definition of crime is expansive under the statute and includes many crimes that could also be employment discrimination if they occurred in the workplace: "rape; torture; trafficking; ... sexual assault; abusive sexual contact; prostitution; sexual exploitation; . . . being held hostage; peonage; involuntary servitude; slave trade; kidnapping; abduction; unlawful criminal restraint; false imprisonment; blackmail; extortion; ... witness tampering; obstruction of justice; perjury; fraud in foreign labor contracting." 8 U.S.C. § 1101(a)(15)(U)(iii).

30. S. POVERTY L. CTR., supra note 28. 
social security numbers. ${ }^{31}$ This conflicting treatment of workers by different agencies undermines enforcement. ${ }^{32}$ It emboldens employers, like the one in this case, to view immigrant workers as exploitable because they can deport or prosecute their way out of the problem. ${ }^{33}$

Second, the involvement of out-of-country employment recruiters can lead to gaps in liability and jurisdiction when agencies do litigate, especially in cases involving $\mathrm{H}-2 \mathrm{~A} \& \mathrm{H}-2 \mathrm{~B}$ workers. In EEOC v. Global Horizons, Inc., farms in the United States contracted with a recruiting company that agreed to recruit temporary farm workers for the farms. ${ }^{34}$ The company recruited workers in Thailand and obtained $\mathrm{H}-2 \mathrm{~A}^{35}$ temporary work visas for the workers. ${ }^{36}$ The workers were specifically recruited because of their national origin because the company believed that "Thai workers would be more compliant and less likely to escape or cause other problems." 37 Once the workers arrived in the United States, the company sent them to several different farms. ${ }^{38}$ The company withheld their identification documents, subjected them to uninhabitable living conditions,

31. Monica Mercer, Cases highlight competing interests in immigration policy, TIMES FREE PRESS (Mar. 9, 2010), http://www.timesfreepress.com/news/news/story/2010/mar/09/cases-highlightcompeting-interests-in/8637/ [https://perma.cc/3ZZK-4CJZ] (reporting that the judge called the case "the most 'bizarre, Alice-in-Wonderland' scenario he ever has encountered in the world of government prosecutions").

32. Morrison, Executive Estoppel, supra note 1, at 320-21 (citing cases).

33. See Saucedo, supra note 1, at 968-71. Moreover, it is likely that this conflicting treatment may increase, given recent reports of the largest workplace raid since the Bush administration. Maria Sacchetti, ICE raids meatpacking plant in rural Tennessee; 97 immigrants arrested, WASH. POST, Apr. 6, 2018, at A2 [https://perma.cc/438V-5AYJ]. The raid was conducted on a meatpacking plant by Immigration \& Customs Enforcement (ICE) and the IRS. Id. They arrested ninety-seven workers and have not charged the employer. Id. This despite that the IRS Special Agent who filled out the affidavit for the warrant stated that the plant "hired undocumented workers who were paid in cash and subject to harsh conditions, including long hours without overtime and exposure to bleach and other chemicals without protective eyewear." Id.

34. EEOC v. Global Horizons, Inc. (Global Horizons I), 904 F. Supp. 2d 1074, 1081 (D. Haw. 2012).

35. H-2A visas are temporary work visas for agricultural labor. Noncitizens who receive such visas are tied to the employer who sponsors the visa. 8 C.F.R. § 214.2(h)(5)(viii)(B)-(C) (2018). To petition for a H-2A nonimmigrant visa, the employer must: Offer a job that is of a temporary or seasonal nature; demonstrate that there are not enough U.S. workers who are able, willing, qualified, and available to do the temporary work; and, show that employing H-2A workers will not adversely affect the wages and working conditions of similarly employed U.S. workers. See generally 8 U.S.C. $\S 1101(\mathrm{a})(15)(\mathrm{H})(\mathrm{ii})(\mathrm{a}) ; 8$ C.F.R. $\S 214.2$ (h)(5) (regulations governing filing a petition for H-2A visas).

36. Global Horizons I, 904 F. Supp. 2d at 1081 (describing the allegations in the EEOC's Complaint).

37. Global Horizons II, 7 F. Supp. 3d 1053, 1062 (D. Haw. 2014).

38. Id. at 1057. 
provided them insufficient food, and subjected them to physical violence. $^{39}$ When the workers complained, the company disciplined them, threatened to transfer them, denied them transportation and food, and threatened them with deportation or arrest. ${ }^{40}$

Eventually, some of the workers filed a charge of discrimination with the EEOC. ${ }^{41}$ The EEOC filed suit against the recruiting company and the farms at which the company placed the workers. ${ }^{42}$ The court granted summary judgment to the EEOC on its claims as to the recruiting company and one of the farms, and the EEOC settled with the other farms. ${ }^{43}$

At the same time, the DHS opened an investigation into how the Thai workers recruited by the company received their H-2A visas and whether the grant of the H-2A visas was fraudulent. ${ }^{44}$ DHS ended up referring the company's CEO, three executives, and two recruiters to the DOJ for criminal prosecution on trafficking and related offenses. ${ }^{45}$ DOJ obtained indictments, and three of the defendants pled guilty. ${ }^{46}$ Two defendants were not in the United States, leaving DOJ unable to prosecute all of them. ${ }^{47}$ The transnational aspect of employment recruiting for temporary work visas, then, means that some of the bad actors can escape prosecution.

In turn, that bad actors can escape prosecution makes workers more vulnerable because it leaves those bad actors able to continue to exploit

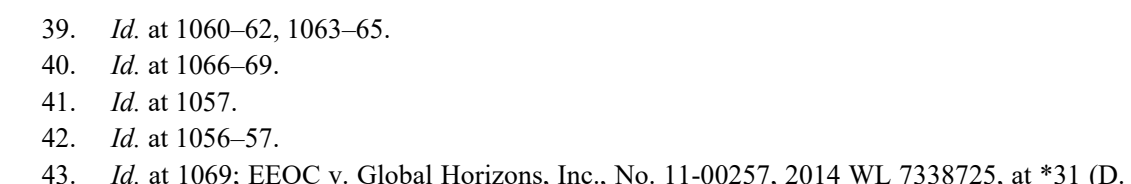
Haw. Dec. 19, 2014); Judge Approves \$2.4 Million EEOC Settlement with Four Hawaii Farms for over 500 Thai Farmworkers, EEOC (Sept. 5, 2014), https://www.eeoc.gov/eeoc/newsroom/release/95-14.cfm [https://perma.cc/52QW-LYAP].

44. Lee Davidson, Utah slavery part of big human trafficking case: Thais in Utah case are linchpins who brought on federal investigation, SALT LAKE TRIB. (Sept. 22, 2010, 2:21 PM), http://archive.sltrib.com/article.php?id=50301390\&itype=CMSID [https://perma.cc/3F9L-QTLH].

45. Id.

46. EEOC v. Global Horizons, Inc., No. 11-00257, 2012 WL 874868, at *1 (D. Haw. Mar. 13, 2012).

47. Id. Subsequently, the three defendants who pled guilty withdrew their guilty pleas, and the DOJ dismissed all of the indictments. Malia Zimmerman, Exclusive: Global Horizons CEO Speaks Out About Human Trafficking Allegations - and the Justice Department's Decision to Drop the Charges, HAW. REPORTER (July 24, 2012), http://www.hawaiireporter.com/exclusive-global-horizons-ceo-speaks-out-about-human-trafficking-allegations-and-the-justice-departments-decision-todrop-the-charges/ [https://perma.cc/7HXH-HB5X]. Although the DOJ would not state why it dismissed the indictments, in another trafficking case, one of the lead prosecutors had misrepresented when the trafficking law that formed the basis of the charges went into effect. Id.; AP, Feds dismiss largest US human trafficking case, FoX News (July 20, 2012), http://www.foxnews.com/us/ 2012/07/20/feds-dismiss-largest-us-human-trafficking-case.html [https://perma.cc/D77X-4C22]. 
and discriminate against workers. Indeed, the Southern Poverty Law Center has reported that some workers have faced extortion from out-of-country recruiters who threatened to harm their family members in their home country if they refuse to pay additional money. ${ }^{48}$ And because U.S. antidiscrimination laws do not extend extra-territorially, "foreign recruiters can openly discriminate against workers seeking temporary visas for employment in the United States." 49

Finally, recent Supreme Court decisions have made it more difficult for noncitizen victims of systemic discrimination to enforce their rights. ${ }^{50}$ Plaintiffs in employment discrimination cases face challenges in moving beyond the pleading stage to a trial on the merits, ${ }^{51}$ on their ability to prove a pattern or practice discrimination claim, ${ }^{52}$ and on their ability to receive class certification. ${ }^{53}$ And increasingly employees cannot even get through the courtroom door due to employer use of mandatory arbitration clauses. ${ }^{54}$ These gaps in access to courts exacerbate the vulnerability of noncitizen workers who already fear coming forward. ${ }^{55}$ Inconsistent and under-enforcement of anti-discrimination laws by federal agencies, jurisdictional gaps, and procedural barriers have left noncitizen workers more vulnerable to employer discrimination and exploitation than citizen workers.

\section{B. Anti-immigrant Narrative has Led to Further Marginalization}

Demographers Douglas Massey and Karen Pren have described a "Latino threat" narrative that presents migrant inflow to the United States as a "violation of American sovereignty by hostile aliens who were increasingly framed as invaders and criminals."

\footnotetext{
48. S. POVERTY L. CTR., supra note 13, at 10-12.

49. Lance Compa, Migrant Workers in the United States: Connecting Domestic Law with International Labor Standards, 92 CHI.-KENT L. REV. 211, 223 (2017) (citing Reyes-Gaona v. N. Carolina Growers Ass'n, 250 F.3d 861 (4th Cir. 2001)).

50. Morrison, EEOC as Fist, supra note 1.

51. Charles A. Sullivan, Plausibly Pleading Employment Discrimination, 52 WM. \& MARY L. REV. 1613 (2011) (looking at impact of the decisions in Ashcroft v. Iqbal, 556 U.S. 662 (2009), and Bell Atl. Corp. v. Twombly, 550 U.S. 544 (2007), on employment discrimination claims).

52. Morrison, EEOC as Fist, supra note 1.

53. Id. at 89-91, 110-18.

54. See Jean R. Sternlight, Tsunami: AT\&T Mobility LLC v. Concepcion Impedes Access to Justice, 90 OR. L. REV. 703, 703-09 (2012) (analyzing the impact the Court's decision in AT\&T Mobility LLC v. Concepcion, 563 U.S. 333 (2011), will have on employment discrimination claims).

55. Morrison, EEOC as Fist, supra note 1, at $143 \&$ n. 343.

56. Douglas S. Massey \& Karen A. Pren, Unintended Consequences of US Immigration Policy: Explaining the Post-1965 Surge from Latin America, 38 Population \& DEV. REV. 1, 5 (2012).
} 
decades and was fed by media accounts. ${ }^{57}$ This aligns with other scholars' accounts of the creation of "the criminal alien"- - a mistaken perception of unauthorized workers as criminals. ${ }^{58}$ Government enforcement efforts have played into the narrative; the past two decades have seen a $1144 \%$ rise in immigration-related criminal prosecutions. ${ }^{59}$ The last year has seen an even greater increase in immigration-related prosecutions, resulting in a decline in prosecutions for other types of crimes. ${ }^{60}$ Similarly, stereotypes based on race and gender about who is a victim and who is a criminal have also led to an increased perception of noncitizen workers as criminals. ${ }^{61}$

Massey and Pren have tied a rise in the "Latino threat" narrative to an increase in restrictionist immigration policies within the United States:

15 restrictive immigration bills passed from 1965 to $2010 \ldots$.. [O]ver time restrictionist bills were passed at an increasingly rapid pace. In the 30 years from 1965 to 1995 , for example, only six major immigration bills were enacted, whereas in the decade from 1996 to 2006, eight pieces of legislation were signed into law. [There were also] 16 named enforcement operations launched between 1993 and 2010. They typically were

57. Id. Recent examples of the Trump administration perpetuating the Latino threat narrative abound, despite no factual basis for the administration's claims. See, e.g., Eugene Scott, In reference to 'animals,' Trump evokes an ugly history of dehumanization, WASH. POST (May 16, 2018), https://www.washingtonpost.com/news/the-fix/wp/2018/05/16/trumps-animals-comment-on-undocumented-immigrants-earn-backlash-historical-comparisons/?utm_term=.b9a23b91281b [https://perm a.cc/S6KL-679G]; Scott Horsley, FACT CHECK: Trump, Illegal Immigration And Crime, NPR (June 22, 2018, 4:49 PM), https://www.npr.org/2018/06/22/622540331/fact-check-trump-illegal-immigration-and-crime [https://perma.cc/4XUK-GEMU].

58. Jennifer M. Chacón, Tensions and Trade-Offs: Protecting Trafficking Victims in the Era of Immigration Enforcement, 158 U. PA. L. REV. 1609, 1628-36 (2010). Some labor rights advocates in arguing against trade agreements also have overstated or misstated the economic impact of immigrants - particularly unauthorized immigrants - on wages and unemployment rates. E.g., Brian Mackey, Racing to the Bottom-With the Pedal to the Metal: Re-Thinking, Reviewing, and Revising NAFTA, 19 L. \& BUS. REV. AM. 357, 365-66 (2013). The evidence is mixed on immigrants' impact on wages and unemployment, but economists do agree that they make a net contribution to the overall economy. See Wage war: Who are the main economic losers from low-skilled immigration?, THE E CONOMIST (Aug. 25, 2016), https://www.economist.com/news/united-states/21705699-who-aremain-economic-losers-low-skilled-immigration-wage-war [https://perma.cc/XFT5-3K76]; Eduardo Porter, The Danger From Low-Skilled Immigrants: Not Having Them, N.Y. TIMES (Aug. 8, 2017), https://www.nytimes.com/2017/08/08/business/economy/immigrants-skills-economy-jobs.html [https://perma.cc/E5NP-5VJZ]; see also Compa, supra note 49, at 216 (summarizing Kati L. Griffith, U.S. Migrant Worker Law: The Interstices of Immigration Law and Labor and Employment Law, 31 COMP. LAB. L. \& POL'Y J. 125, 127-28 (2009)).

59. Criminal Immigration Convictions Drop 20 Percent, TraC IMMigration, (June 12, 2015), http://trac.syr.edu/immigration/reports/392 [https://perma.cc/Z257-LXTE].

60. Stepped Up Illegal-Entry Prosecutions Reduce Those for Other Crimes, TRAC IMMIGRATION (Aug. 6, 2018), http://trac.syr.edu/immigration/reports/524 [https://perma.cc/NB25-J3LK].

61. See Morrison, Executive Estoppel, supra note 1, at 297-98 (first citing Chacón, supra note 58, at 1628-36; then citing Kathleen Kim, The Coercion of Trafficked Workers, 96 IOWA L. REV. 409, $415(2011))$. 
announced with great fanfare, including official releases, press conferences, and saturated media coverage. The pace at which such operations were launched also increased over time. Moreover, they became more sweeping in scope, covering locations within the United States as well as along the Mexico-US border. ${ }^{62}$

The demographers show that this resulted in a policy-feedback that has led to increasingly restrictive immigration laws. ${ }^{63}$

Although the restrictionist laws themselves created the new classes of unauthorized workers, ${ }^{64}$ public perception persists that the United States is under threat. That perception results in more restrictions and enforcement. Beth Lyon has argued that legislators' enforcement-only approach to immigration has resulted in "a series of superficial policy shifts that fail to address the underlying issues, producing an immigration regime that seems to be rudderless, offering only unenforceable laws to address vocal public concern, widespread human suffering, and damage to America's credibility within the international community." 65 Ultimately, gaps in the enforcement of workplace protections, and over-enforcement of immigration laws have left noncitizen workers increasingly unprotected in the workplace.

\section{Worker RightS IN TRADE PROMOTION AUTHORITY \& FREE TRADE AGREEMENTS}

In the last three decades, Congress has included worker rights as one of the negotiating objectives in trade promotion authority. Though the President negotiates and implements trade agreements with other countries, the Congress has the authority to enter into the trade agreements. Since Congress has included worker rights as one of the negotiating objectives in trade promotion authority, recent free trade agreements have included provisions guaranteeing worker rights, including anti-discrimination provisions.

\section{A. Trade Promotion Authority}

Because the Constitution grants Congress the authority to enter trade

\footnotetext{
62. Massey \& Pren, supra note 56, at 6.

63. Id. at $6-8$

64. Id.

65. Beth Lyon, The Unsigned United Nations Migrant Worker Rights Convention: An Overlooked Opportunity to Change the "Brown Collar" Migration Paradigm, 42 N.Y.U. J. INT'L L. \& POL. 389,394 (2010).
} 
agreements, the President must follow Congressional directives in negotiating trade agreements. ${ }^{6}{ }^{6}$ The Constitution does not specify the President's trade authority, but the Constitution grants the President authority "to make Treaties" with the advice and consent of the Senate. ${ }^{67}$ Prior to the 1930s, the President executed his role in trade policy by negotiating and implementing "bilateral treaties of friendship, commerce, and navigation." 68 The President now executes U.S. trade policy as authorized by statute through the United States Trade Representative (USTR), a cabinetlevel position. ${ }^{69}$

While the President through the USTR negotiates and executes trade agreements, the Constitution gives Congress the authority to enter into trade agreements. Article 1, Section 8 of the United States Constitution designates Congress' role in creating U.S. trade policy: "To lay and collect Taxes, Duties, Imposts and Excises, ... To regulate Commerce with foreign Nations, and among the several States, [and] . . . make all Laws which are necessary and proper" to exercise its authority. ${ }^{70}$

Until the 1930s, Congress exercised its trade authority by setting tariff rates on all imported goods. ${ }^{71}$ After Congress passed the Smoot-Hawley Tariff Act of $1930,{ }^{72}$ major U.S. trade partners put into place retaliatory tariffs, "which severely restricted trade and contributed to the deep and prolonged effects of the depression." 73 As a result, Congress passed the first trade-related act that "expressly delegated to the President an expanded trade agreements authority to reduce tariffs within congressionally

66. U.S. CONST. art. I, $\S 8$, cl. 3 .

67. U.S. Const. art. II, § 2, cl. 2; Ian F. Fergusson, Cong. Research Serv., RL33743, Trade Promotion Authority (TPA) and the Role of Congress in Trade Policy 2 (2015) (citing I.M. Destler, American Trade Politics 14 (Washington DC: Institute for International Economics eds., 4th ed. 2005)).

68. FERGUSSON, supra note 67.

69. 19 U.S.C. § 2171(a)-(b) (2012 \& Supp. 2017). The Office of the United States Trade Representative oversees the United States' trade negotiations with other countries and resolves trade disputes under U.S. trade agreements. About Us, OfFICE OF THE UNITED STATES TRADE REPRESENTATIVE, www.ustr.gov/about-us [https://perma.cc/UA2C-CK3C](last visited Oct. 4, 2018). The USTR has "primary responsibility for developing, and for coordinating the implementation of, United States international trade policy." 19 U.S.C. § 2171(c)(1)(A). The USTR also is the President's principal trade advisor, "chief representative" of the United States in all international trade negotiations, "principal spokes[person] of the President on international trade," and chairperson of the interagency trade organization. Id. $\S 2171(\mathrm{c})(1)(\mathrm{B})-(\mathrm{C})$, (E), (I). Reporting to Congress and the President, issuing and coordinating policy guidance to other agencies on trade policy, interpreting issues arising "in the exercise of international trade functions," and assuming any other tasks that the President may direct are among the USTR's other duties. Id. § 2171(c)(1)(D)-(H), (J).

70. U.S. CONST. art. I, $\S 8$.

71. FERGUSSON, supra note 67.

72. Pub. L. No. 71-361, 46 Stat. 590.

73. FERGUSSON, supra note 67 , at 3. 
predefined ranges." $" 74$

In subsequent decades, Congress reauthorized the President's ability to cut tariffs through extension Acts. ${ }^{75}$ The cuts led to a diminished role in trade policy for tariffs, and "negotiations shifted from bilateral to multilateral." "76 Those two changes meant that Congress needed to change federal law for the United States to effectively negotiate agreements. ${ }^{77}$ Trade partners needed to know that Congress would consider agreements within a definite timeframe, and that negotiated agreements would not be "subject to unlimited congressional debate and amendment."78 But Congress still wanted to prevent the President from encroaching on Congressional authority. ${ }^{79}$

Congress settled on a solution. Through what was called "fast track authority" and is now called "trade promotion authority," Congress set four main priorities:

(1) to define trade policy priorities and to have those priorities reflected in trade agreement negotiating objectives; (2) to ensure that the executive branch adheres to these objectives by requiring periodic notification and consultation with Congress; (3) to define the terms, conditions, and procedures ... under which the respective implementing bills may be approved; and (4) to reaffirm Congress's overall constitutional authority over trade by placing limitations on the trade agreements authority. ${ }^{80}$

Trade promotion authority also presents advantages to the President because it has an expedited approval process. ${ }^{81}$

\section{B. Worker Rights in Trade Promotion Authority}

The Bipartisan Congressional Trade Priorities and Accountability Act

\footnotetext{
74. Id.

75. Id. at 3, 21 app. A.

76. Id. at 3 .

77. Id. at 4 (citing Trade Expansion Act of 1962, Pub. L. No. 87-794, 76 Stat. 872 (codified as amended in scattered sections of 19 U.S.C.)).

78. Id. at $4-5$.

79. Id. at 4 .

80. Id. at $8-9$.

81. LaEl Brainard \& Hal Shapiro, The Brookings InSt., FASt Track Trade Promotion AUTHORITY 3 (2001). First, any qualifying trade agreement entered into pursuant to the authority must be introduced through an implementing bill in both Congressional chambers. Id. Second, the bill is referred to relevant committees, and there is a minimum period of time that the bill is discharged if the committee has not reported it out. Id. Third, there are no amendments to and limited debate on the agreement once it hits the floor in each chamber. $I d$. The bill receives an up or down vote. Id. Finally, the bill will not have to go to the conference committee since the bills in each chamber are identical. $I d$.
} 
of 2015 is the latest iteration of trade promotion authority. ${ }^{82}$ Its provisions include significant changes to United States' priorities with respect to workers' rights. Prior iterations of trade promotion authority required trade negotiators to ensure parties agreed to "effectively enforce [their] . . . labor laws." 83 The 2015 Act builds on that objective to promote regulatory coherence, to expand what rights the labor laws must recognize, and to make labor disputes subject to the same dispute resolutions as other types of trade disputes. ${ }^{84}$

While prior trade promotion authority included negotiating objectives related to regulatory practices, the 2015 Act also promotes improved regulations and regulatory cohesion. ${ }^{85}$ It requires negotiators to "establish consultative mechanisms and seek other commitments, as appropriate, to improve regulatory practices and promote increased regulatory coherence." 86

The 2015 Act also includes two changes with respect to worker rights: (1) it expands the labor objectives to include the elimination of discrimination in employment; and (2) it subjects labor disputes to the same dispute mechanisms as other trade disputes. ${ }^{87}$ First, the 2015 Act adds as a trade negotiating objective "to promote respect for worker rights . . consistent with the core labor standards of the [International Labor Organization]... and an understanding of the relationship between trade and worker rights." ${ }^{" 88}$ Section 102(b)(10) requires the United States to ensure that parties to trade agreements "adopt[] and maintain[] measures implementing . . c core labor standards," and "effectively enforce" their statutes or regulations implementing those core labor standards. ${ }^{89}$ The Act's definition of "core labor standards" mirrors the principles contained in a Declaration of the International Labor Organization:

(A) freedom of association; (B) the effective recognition of the right to collective bargaining; (C) the elimination of all forms of forced or compulsory labor; (D) the effective abolition of child labor and a prohibition

\footnotetext{
82. Pub. L. No. 114-26, 129 Stat. 320.

83. Trade Act of 2002, Pub. L. No. 107-210, § 2102(b)(11)(A), 116 Stat. 933, 1000.

84. Bipartisan Congressional Trade Priorities \& Accountability Act of $2015 \S 102(b)(7),(10)$.

85. Compare id. $\S 102(\mathrm{~b})(7)$ (setting forth the principle negotiating objectives for regulatory practices), with Trade Act of $2002 \S 2102$ (b)(11) (setting out the principle negotiating objectives for regulatory practices).

86. Bipartisan Congressional Trade Priorities \& Accountability Act of $2015 \S 102(b)(7)(C)$.

87. Compare id. $\S 102(b)(10)$ (setting forth the principle negotiating objectives for labor and the environment), with Trade Act of $2002 \S 2102$ (b)(11) (setting out the principle negotiating objectives for labor and the environment).

88. Bipartisan Congressional Trade Priorities \& Accountability Act of $2015 \S 102(a)(6)$.

89. Id. § 102(b)(10).
} 
on the worst forms of child labor; and (E) the elimination of discrimination in respect of employment and occupation. ${ }^{90}$

Thus, unlike prior iterations of trade promotion authority, the 2015 Act includes all of the international labor standards embodied in the International Labor Organization's (ILO) statement of fundamental principles. ${ }^{91}$ Using the ILO's labor principles expands the negotiation objectives beyond ensuring freedom of association, collective bargaining rights, and the end of child labor, to eliminating employment discrimination.

Second, the 2015 Act requires that complaints about violations of the workplace rights provisions go through the same dispute mechanisms as other types of trade disputes. It lists as one of the negotiation objectives "to ensure that enforceable labor ... obligations are subject to the same dispute settlement and remedies as other enforceable obligations under the agreement." 92

Like prior trade promotion authority, the 2015 Act has sunset provisions. ${ }^{93}$ The Act allows the President to enter into trade agreements without prior approval by Congress - and subject to the limitations set out in the 2015 Act—-before July 1, 2018. ${ }^{94}$ The Act provided, however, that the President could request an extension of the trade authority. ${ }^{95}$ As long as

90. Id. § 111(7); ILO, ILO Declaration on Fundamental Principles and Rights at Work and its Follow-up 7 (adopted June 18, 1998, rev. June 15, 2010). Congress added the phrase "a prohibition on the worst forms of child labor" to the language of 19 U.S.C. $\S 4210(7)(D)$ (2017). Congress also specifically defined "internationally recognized core labor standards" as "the core labor standards only as stated in the ILO Declaration on Fundamental Principles and Rights at Work and its Follow-Up." Bipartisan Congressional Trade Priorities \& Accountability Act of $2015 \S 111$ (17). The 2002 Act also mirrored some of the ILO labor principles. But the 2002 Act did not include employment discrimination and had different language with respect to child labor and coerced labor:

The term 'core labor standards' means - (A) the right of association; (B) the right to organize and bargain collectively; $(\mathrm{C})$ a prohibition on the use of any form of forced or compulsory labor; (D) a minimum age for the employment of children; and (E) acceptable conditions of work with respect to minimum wages, hours of work, and occupational safety and health.

Trade Act of $2002 \S 2113(6)$.

91. The ILO is made up of representatives from governments, employers, and unions. Sandra Polaski, Protecting Labor Rights Through Trade Agreements: An Analytical Guide, 10 U.C. DAVIS J. INT'L L. \& POL'Y 13, 16-17 (2003). When the ILO adopts a convention, normally, only countries that have ratified it are bound by the convention. Id. at 17. But if the ILO determines something is a "fundamental right," then "each member country must observe those rights, regardless of whether its government has ratified the relevant conventions." Id.

92. Bipartisan Congressional Trade Priorities \& Accountability Act of $2015 \S 102(\mathrm{~b})(10)(\mathrm{H})$.

93. Id. $\S 103$.

94. Id. $\S 103(\mathrm{c})(1)(\mathrm{A})-(\mathrm{B})$.

95. Id. $\S 103(\mathrm{c})(1)(\mathrm{B})$. 
"neither House of Congress adopts an extension disapproval resolution . . . before July 1, 2018," the Act extends the trade authorization through July $1,2021 .{ }^{96}$ President Trump requested an extension of the trade authority, ${ }^{97}$ and Congress did not adopt an extension disproval. ${ }^{98}$ Thus, the President's ability to enter into trade agreements under the Act is extended through July 1, 2021.

\section{Worker Rights in Free Trade Agreements}

In a series of Free Trade Agreements, beginning with the North American Agreement on Labor Cooperation (NAALC) ${ }^{99}$ and its renegotiation, ${ }^{100}$ to the now-defunct Trans Pacific Partnership (TPP), ${ }^{101}$ to the proposed U.S.-Canada-Mexico Agreement (USMCA), ${ }^{102}$ the United States has negotiated for labor protections pursuant to trade promotion authority. ${ }^{103}$ "Since 1993, the United States has negotiated 13 [free trade agreements] that include 19 countries." 104 Only six of the agreements contained provisions requiring or encouraging party states to eliminate discrimination with respect to employment. ${ }^{105}$ But it is only the most recent agreements that have included enforceable anti-discrimination in employment

96. Id.

97. Message from President Donald Trump to the Congress of the United States (Mar. 20, 2018), https:/www.whitehouse.gov/briefings-statements/presidential-message-congress-united-states-3/ [https://perma.cc/H3WK-G9YU].

98. See Press Release, OfFICE of the United States Trade RePresentative (June 2018), https:/ustr.gov/about-us/policy-offices/press-office/press-releases/2018/june/ustr-lighthizer-welcomes-extension [https://perma.cc/DCJ8-L3B3].

99. North American Agreement on Labor Cooperation, Can.-Mex.-U.S., opened for signature Sept. 8, 1993, 32 I.L.M. 1499.

100. North American Free Trade Agreement, Can.-Mex.-U.S., Dec. 17, 1992, 32 I.L.M. 289 (entered into force Jan. 1, 1994).

101. TPP Full Text, OFFICE OF THE UNITED STATES TRADE REPRESENTATIVE, https://ustr.gov/ trade-agreements/free-trade-agreements/trans-pacific-partnership/tpp-full-text [https:/perma.cc/ D9GE-7LP2] (last visited Oct. 6, 2018).

102. U.S.-Mex.-Can. Agreement Text, Office Of the United States Trade RePresentative, https:/ustr.gov/trade-agreements/free-trade-agreements/united-states-mexico-canada-agreement/ united-states-mexico [https://perma.cc/H5K5-76SD] (last visited Oct. 21, 2018) (the author has also retained a hard copy of Chapter 23 (Labor Provisions), Chapter 28 (Good Regulatory Practices), and Chapter 31 (Dispute Settlement) of the draft text of the USMCA).

103. Mary Jane Bolle, Cong. Research Serv., RS22823, Overview of Labor Enforcement Issues in Free Trade Agreements 2 (2016).

104. Id.

105. Id. at 3. The U.S.-Jordan Fair Trade Agreement, the U.S.-Chile Fair Trade Agreement, the U.S.-Singapore Fair Trade Agreement, the U.S.-Australia Fair Trade Agreement, the U.S.-Morocco Fair Trade Agreement; the U.S.-Bahrain Fair trade Agreement, the U.S.-Oman Fair Trade Agreement, and CAFTA-DR (between the U.S., Costa Rica, El Salvador, Guatemala, Honduras, Nicaragua, and the Dominican Republic) only required signatories to enforce U.S.-defined "internationally recognized worker rights." Id. This standard requires "acceptable conditions of work with respect to minimum 
provisions. The NAALC, TPP, and USMCA illustrate the difference in enforceability. The former, entered into in 1993, has an anti-discrimination provision but it is not enforceable; the latter two, the TPP concluded in 2016 and the USMCA negotiated in 2018, have anti-discrimination provisions that are enforceable.

NAALC $^{106}$ is a side agreement to the North American Free Trade Agreement (NAFTA). ${ }^{107}$ When the United States signed the NAALC in 1993, it was the first time it had entered into a trade agreement that imposed labor obligations on not only the other parties to the agreement, but also the United States. ${ }^{108}$ It also includes a greater number of recognized labor principles than prior agreements. ${ }^{109}$

Prior to the Bipartisan Congressional Trade Priorities \& Accountability Act of 2015, United States trade law had recognized five "internationally recognized worker rights," which included: "(1) the right of association; (2) the right to organize and bargain collectively; (3) prohibition of forced or compulsory labor; (4) a minimum age for employment of children; and (5) acceptable conditions for worker rights with respect to minimum wages, hours of work, and occupational health and safety." 110 The NAALC expanded the definition of core workers' rights to include workers' compensation, migrant worker protections, freedom from employment discrimination, and equal pay for men and women. ${ }^{111}$ In this way it recognized the same fundamental labor rights as the ILO and included the

\footnotetext{
wages, hours of work, and occupational safety and health." Id. at 4. Those agreements, then, do not require signatories to adopt or enforce anti-discrimination laws.

106. North American Agreement on Labor Cooperation, supra note 99.

107. North American Free Trade Agreement, supra note 100.

108. BOLLE, supra note 11 , at 1 .

109. Id. at 3 .

110. Id. at 3 n.5.

111. North American Agreement on Labor Cooperation, art. 49(1)(a)-(k), supra note 99, at 1513-14:
}

'Labor law' means laws and regulations, or provisions thereof, that are directly related to: (a) freedom of association and protection of the right to organize; (b)the right to bargain collectively; (c) the right to strike; (d) prohibition of forced labor; (e) labor protections for children and young persons; (f) minimum employment standards, such as minimum wages and overtime pay, covering wage earners, including those not covered by collective agreements; $(\mathrm{g})$ the elimination of employment discrimination on the basis of grounds such as race, religion, age, sex, or other grounds as determined by each Party's domestic laws; (h) equal pay for men and women; (i) prevention of occupational injuries and illnesses; (j) compensation in cases of occupational injuries and illnesses; $(\mathrm{k})$ protection of migrant workers. 
additional principles of migrant worker protections and workers' compensation. ${ }^{12}$

When parties violate their obligations under NAALC, they do not go through the same dispute resolution process as other trade violations under NAFTA. ${ }^{13}$ To enforce the workers' rights principles, the NAALC relies mainly on voluntary cooperation and consultation. ${ }^{114}$ The NAALC only provides for sanctions when a country violates three principles: labor protections for children, minimum wage standards, and the prevention of occupational injuries and illnesses. ${ }^{115}$

The United States renegotiated NAFTA with Mexico and Canada. ${ }^{116}$ The administration negotiated with Mexico first and notified Congress on August 31, 2018 of the agreement pursuant to the 2015 trade promotion authority. ${ }^{117}$ Subsequently, Canada and the U.S. agreed that Canada would join the agreement and the administration announced Canada's inclusion and a new name for the agreement - the U.S.-Mexico-Canada Agreement (USMCA). ${ }^{118}$ In renegotiating NAFTA, the USTR brought the labor provisions into the core agreement, rather than placing the provisions in a side agreement. ${ }^{119}$ The USMCA also will require parties to "adopt and maintain in [their] statutes and regulations, and practices thereunder" the rights embodied in the ILO's statement of fundamental principles. ${ }^{120}$ Thus, the labor rights in the USMCA match those in the Bipartisan Congressional Trade Priorities \& Accountability Act of 2015, and include the "[e]limination of discrimination in respect of employment and occupation."121 Similarly, the USMCA requires parties to "effectively enforce their labor laws." 122 Finally, the USMCA's labor obligations are subject to the same dispute settlement mechanism as the other enforceable obligations of USMCA. ${ }^{123}$

Although the United States failed to ratify the TPP, ${ }^{124}$ it provides an

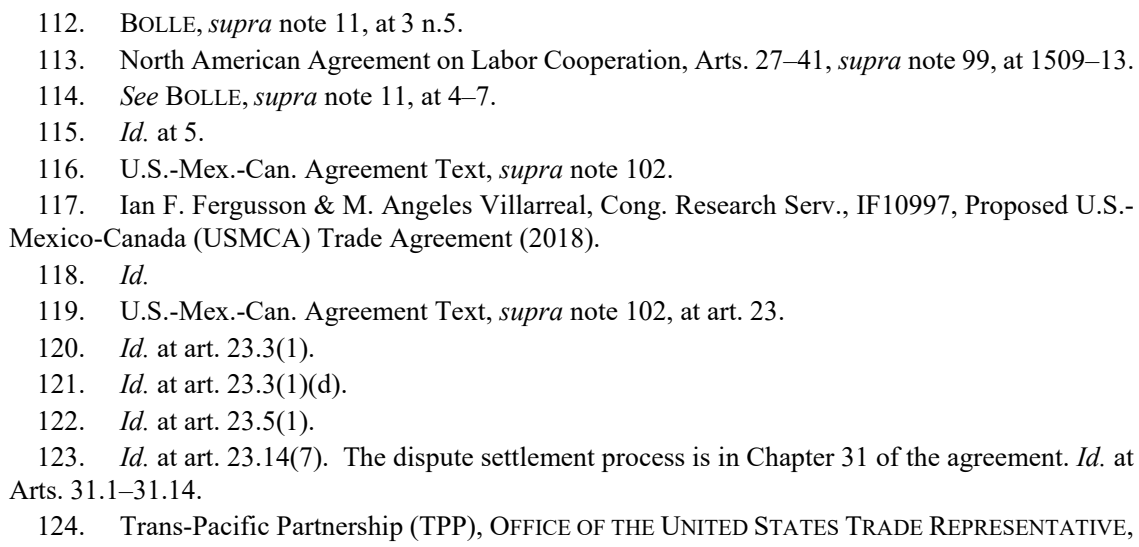


example of what a trade agreement under the 2015 trade promotion authority would look like because at the time that the United States negotiated and concluded its negotiations on the TPP, the agreement was subject to the Bipartisan Congressional Trade Priorities \& Accountability Act of 2015. And the TPP provides an example of what the employment discrimination provisions and attendant enforcement mechanisms will look like in the finalized version of the USMCA. ${ }^{125}$ Since the final negotiated text of the TPP is available, this article uses the TPP as an exemplar rather than the USMCA. The USMCA is still in draft form and subject to revisions.

The TPP has a set of obligations and a set of aspirations with respect to employment discrimination and regulatory coherence. Among the obligations are that parties shall not "fail to effectively enforce [their] labour laws through a sustained or recurring course of action or inaction in a manner affecting trade or investment." ${ }^{26}$ The TPP requires each party to "adopt and maintain in its statutes and regulations, and practices thereunder, ... the elimination of discrimination in respect of employment and occupation." 127 A party must ensure that "persons with a recognised in-

https://ustr.gov/trade-agreements/free-trade-agreements/trans-pacific-partnership\# [https://perma.cc /E444-V4CS] (last visited Oct. 6, 2018).

125. As of September 21, 2018, the USMCA negotiations are concluded, but the parties have not finalized and signed the agreement. The draft version of the agreement is available and its provisions resemble those in the TPP because the agreement must meet the standards in the 2015 Trade Promotion Authority (TPA) to go through the TPA's expedited approval procedures. M. ANGELES VILLARREAL \& IAN F. FERGUSSON, CONG. RESEARCH SERV., R44981, NAFTA RENEGOTIATION AND MODERNIZATION 12 (2018). Additionally, Robert Lighthizer, the U.S. Trade Representative, said that the administration was "building on what was done in T.P.P." Mark Landler \& Allen Rappeport, Trump Hails Revised Nafta Trade Deal, and Sets Up a Showdown With China, N.Y. TIMES (Oct. 1. 2018), https://www.nytimes.com/2018/10/01/us/politics/nafta-deal-trump-canada-mexico.html [https://perma.cc/Q9CY-9RQ6].

126. TPP Full Text, supra note 101, at art. 19.5(1).

127. Id. at art. 19.3(1)(d). It also requires parties to adopt statutes and regulations of other rights stated in the ILO, including the freedom of association, collective bargaining rights, elimination of all forms of forced or compulsory labor, and the effective abolition of child labor and a prohibition on the worst forms of child labor. Id. at art. 19.3(1)(a)-(c). The USMCA labor chapter differs somewhat from the TPP because it provides additional provisions on forced or compulsory labor, U.S.-Mex.Can. Agreement Draft Text, supra note 102, at art. 23.6, violence against workers, id. at art. 23.7, migrant workers, $i d$. at art. 23.8, and sex-based discrimination in the workplace, $i d$. at art. 23.9. Regarding migrant workers, the USMCA requires that "each Party shall ensure that migrant workers are protected under its labor laws, whether they are nationals or non-nationals of the Party." Id. at art. 23.8. And regarding sex-based discrimination, the USMCA requires that "each Party shall implement policies that protect workers against employment discrimination on the basis of sex, including with regard to pregnancy, sexual harassment, sexual orientation, gender identity, and caregiving responsibilities, provide job-protected leave for birth or adoption of a child and care of family members, and protect against wage discrimination." Id. at art. 23.9. 
terest under its law . . . have appropriate access to impartial and independent tribunals for the enforcement of the Party's labour laws." 28 The proceedings for the enforcement of labor laws must be "fair, equitable and transparent." 129 Individuals involved in the proceedings should have a right to appeal ${ }^{130}$ and access to remedies that ensure the enforcement of their rights under the country's labor laws. ${ }^{131}$ Finally, signatory countries must promote public awareness of the country's labor laws by making information related to their labor laws publicly available. ${ }^{132}$

Among the TPP's aspirations are the provisions related to regulatory coherence. Parties shall "endeavor" to achieve regulatory coherence in its domestic laws. ${ }^{133}$ The Agreement encourages parties to bulk up interagency consultation and regulation, so agencies can identify overlap, duplication, and "inconsistent requirements across agencies." 134 And parties' domestic agencies should have the ability to "make recommendation for systemic regulatory improvements." 135

The TPP's dispute resolution process for workers' rights differs from that in NAALC because it was subject to the 2015 Trade Promotion Authority's objectives. So, a party's violations of the Labor provisions are subject to the same enforcement mechanisms as violations of other trade provisions. Parties to the TPP may seek enforcement through four main mechanisms: (1) voluntary cooperation, ${ }^{136}$ (2) transparency and public

\footnotetext{
128. Id. at art. 19.8(2).

129. Id. at art. 19.8(3).

130. Id. at art. 19.8(5).

131. Id. at art. 19.8(6).

132. Id. at art. 19.8(1).

133. Id. at art. 25.4(1).

134. Id. at art. 25.4(2)(b).

135. Id. at art. 25.4(2)(c).

136. Id. at arts. 19.10, 19.11, 28.2. The Labor article provides for two methods of voluntary cooperation, one is through general cooperative activities, $i d$. at art. 19.10, and the other is cooperative labor dialogue, $i d$. at art. 19.11. In the latter, a "Party may request dialogue with another Party on any matter arising under [the Labor chapter] at any time by delivering a written request to [the other Party]." Id. at art. 19.11(1). The dialogue is an informal way to work through a matter of non-compliance with another party short of formal consultation or dispute settlement. See id. at art. 19.11. It can occur while undergoing consultation. Id. at art. 19.15(14). To facilitate cooperation the TPP requires that parties establish a Labor Council, which serves an advisory and governing function. See $i d$. at art. 19.12. It produces reports and reviews labor provisions. Id. The TPP also requires parties to designate a contact point, who "facilitate[s] regular communication and coordination between the [p]arties[,]" reports to the Labor Council, and can "develop and implement specific cooperative activities bilaterally or plurilaterally." Id. at art. 19.13(2)-(3).
} 
awareness, ${ }^{137}$ (3) formal consultations, ${ }^{138}$ and (4) dispute settlement. ${ }^{139}$

The Labor Chapter also requires parties to allow complaints from nonparties: "[e]ach party . . . shall provide for the receipt and consideration of written submissions from persons of a Party on matters related to [labor matters under the TPP] in accordance with its domestic procedures." 140 When a party receives a submission, it must consider the merits of the submission and provide a timely response. ${ }^{141}$ It must also make the submission and the party's response to it public, as appropriate. ${ }^{142}$

\section{Despite Potential Challenges to ENForCEMENT, THE ANTI- DISCRIMINATION PROVISION WILL REINFORCE THE WORKPLACE RIGHTS OF NONCITIZEN WORKERS}

Provisions in free trade agreements - the requirement that a party enforces its anti-discrimination laws, the regulatory coherence provisions, the public submission process, and the dispute settlement provisionshave the potential to reinforce the rights of noncitizen workers in the

137. Id. at arts. 19.8 (public awareness guarantees), 19.9(3)(b) (make submissions under the agreement public, as appropriate), 19.10(2)(g) (transparency and public participation in cooperative efforts under the agreement), 19.12(7) (Labour Council decisions and reports should be publicly available), 19.13(2)(d) (contact point acts as channel for communication with the public in the party's territory), 19.14(2) (parties should maintain a national labor advisory body to allow for public engagement in labor issues under the TPP), 28.17 (the disputing parties must release the final report generated from the dispute settlement panel to the public).

138. Id. at arts. 19.15, 28.5.

139. Id. at arts. 19.12-19.13, 28.7-28.21. Before parties may submit their dispute to a panel, the parties must first engage in formal consultation. $I d$. at arts. 19.13, 28.7. The USMCA's dispute resolution procedures resemble those in the TPP. U.S.-Mex.-Can. Agreement Text, supra note 102, at art. 31 . Because the regulatory cohesion provisions in the TPP are only aspirational, the only enforcement mechanisms available for violations of the regulatory cohesion provisions are voluntary cooperation and transparency. TPP Full Text, supra note 101, at art. 25.11 ("No party shall have recourse to dispute settlement under Chapter 28 (Dispute Settlement) for any matter arising under this Chapter [Regulatory Coherence]."). The chapter on Regulatory Coherence provides for a Committee on Regulatory Coherence, $i d$. at art. 25.6, and cooperation "to facilitate the implementation of [Regulatory Coherence]", $i d$. at art. 25.7(1). Chapter 25 also includes transparency measures. Id. at arts. 25.4(2)(d) (parties should "publicly report on regulatory measures reviewed, an[d] proposals for systemic regulatory improvements"), 25.5(5) (parties should ensure public access to information on regulatory measures), 25.8 (parties should provide ways for interested person to provide input on the parties' regulatory coherence). The USCMA, however, allows parties to use the dispute settlement process for regulatory coherence violations in limited circumstances: "No Party shall have recourse for dispute settlement ... for a matter arising under [the Good Regulatory Practices chapter] except to address a sustained and recurring course of action or inaction that is inconsistent with a provision of [the Good Regulatory Practices chapter]." U.S.-Mex.-Can. Agreement Text, supra note 102, at art. 28.20(3).

140. TPP Full Text, supra note 101, at art. 19.9(1).

141. Id. at arts. 19.9(2)(c) \& 19.9(3)(a).

142. Id. at art. 19.9(3)(b). 
United States. However, the provisions also present challenges to enforcement. Free trade agreements do not provide a private right of action, a violation must be in a manner affecting trade, and the enforcement mechanisms are not efficient. Nonetheless, the agreements will still reinforce noncitizens' employment rights in three important ways. First, they will fill in gaps in U.S. enforcement; second, they will provide additional incentives to the United States to enforce its anti-discrimination provisions; and third, they provide a frame that will result in political pressure on the U.S. government and employers to respect the rule of law and noncitizen workers' rights.

\section{A. Potential Challenges to Enforcement}

Although free trade agreements strive to eliminate discrimination in employment and create an obligation on the part of member states to effectively enforce their own labor laws, workers and their advocates will face several challenges in using the provisions to enforce their rights. First, trade agreements do not create a private right of action, which means individuals have to rely on a member state to bring a complaint. Second, the party must fail to enforce its labor laws in a manner affecting trade between the parties. Third, the enforcement mechanisms could be ineffective. Finally, only member states are subject to the provisions.

The initial challenge to enforcement is that trade agreements do not generally create a private right of action. NAALC, the TPP, and USMCA are no exception. ${ }^{143}$ All three agreements specifically forbid parties to the agreement from providing a private right of action under their domestic laws. ${ }^{144}$ Although the NAALC, the TPP, and the USMCA require parties to allow submissions to their trade authorities from non-parties, the trade authorities do not have to act on those submissions other than to generate a report. ${ }^{145}$ As a result, only parties may seek enforcement of the antidiscrimination provisions under the trade agreement, and they may only

143. North American Agreement on Labor Cooperation, art. 43, supra note 99, at 1513; U.S.Mex.-Can. Agreement Text, supra note 102, at art. 31.21; TPP Full Text, supra note 101, at art. 28.22.

144. North American Agreement on Labor Cooperation, art. 43, supra note 99, at 1513 ("No Party may provide for a right of action under its domestic law against any other Party on the ground that another Party has acted in a manner inconsistent with this Agreement."); U.S.-Mex.-Can. Agreement Text, supra note 102, at art. 31.21 ("No Party shall provide for a right of action under its law against another Party on the ground that a measure of that other Party is inconsistent with this Agreement."); TPP Full Text, supra note 101, at art. 28.22 ("No Party shall provide for a right of action under its law against any other Party on the ground that a measure of that other Party is inconsistent with its obligations under this Agreement, or that the other Party has otherwise failed to carry out its obligations under this Agreement.").

145. See, e.g., TPP Full Text, supra note 101, at art. 19.9(1)-(3). 
seek enforcement against another party to the agreement. ${ }^{146}$ That means noncitizen workers in the United States who believe that the United States has failed to effectively enforce its anti-discrimination law, have to rely on another signatory state to the agreement to seek enforcement. It also means that the workers, themselves, do not have individual remedies under the agreement.

That workers will have to rely on another member state to enforce the provision presents disadvantages to three specific groups of noncitizens. First, noncitizens who are in the United States as refugees or asylees will not be able to rely on their country of origin to enforce the provision, and they may have a more difficult time getting another state to bring the enforcement action. Asylees and refugees are in the United States because they are "unable or unwilling to return to ... [their] country because of persecution or a well-founded fear of persecution on account of race, religion, nationality, membership in a particular social group, or political opinion." 147 Further, the refugee or asylee must show that she is "unable or unwilling to avail [herself]" of the country's protection. ${ }^{148}$ Because the country itself allowed or perpetrated the persecution, this makes it unlikely that the country would respond to an asylee or refugee's submission.

A second group may have a difficult time getting a member state to seek enforcement because the noncitizens' country of origin is not a member state of the agreement. In 2016, China sent the second largest number of immigrants to the United States, India sent the third largest number, and the Philippines sent the fourth largest. ${ }^{149}$ None of those countries have entered into a trade agreement with the United States. ${ }^{150}$ This means that noncitizens from non-member states would have to lobby a member state, with which they have no connection, to file a submission. For this group and for asylees, it will likely be difficult for them to rely on a country different from their country of origin. They will be expected to figure out that country's procedures for filing a submission. And it could prove difficult to get attention from that country's trade authority if they are unfamiliar with that country's cultural norms and what would be most persuasive to the country's trade authority.

146. North American Agreement on Labor Cooperation, art. 43, supra note 99, at 1513; U.S.Mex.-Can. Agreement Text, supra note 102, at art. 31.21; TPP Full Text, supra note 101, at art. 28.22.

147. 8 U.S.C. $\S 1101(\mathrm{a})(42)(\mathrm{A})(2012)$.

148. Id.

149. Gustavo López \& Kristen Bialik, Key findings about U.S. immigrants, PEw RES. CTR. (Sept. 14, 2018), http://pewrsr.ch/2qz2zvx [https://perma.cc/A4LJ-34VY].

150. Free Trade Agreements, INT'L TRADE ADMIN., https://www.trade.gov/fta/ [https://per ma.cc/4BKQ-FZBW] (last visited Oct. 6, 2018). 
The third group that may have a difficult time getting a member state to seek enforcement are those who have lived in the United States for such an extended period of time that they have few ties to their country of origin. For example, individuals who were brought to the United States as children and grew up in the United States, often more closely identify with United States' culture than the culture of their country of origin. ${ }^{151}$ Noncitizens with more extensive ties to the United States than to their country of origin may face challenges similar to noncitizens who must rely on a country different from their country of origin.

A second challenge to enforcement of the anti-discrimination measures is that the United States must fail to effectively enforce its laws "in a manner affecting trade or investment between the Parties." 152 A recent case that went to arbitration under the Dominican Republic-Central American Free Trade Agreement (CAFTA-DR), ${ }^{153}$ illustrates the difficulty workers may have in demonstrating that the United States failed to effectively enforce its labor laws in a manner affecting trade and development. ${ }^{154}$ American and Guatemalan trade unions filed a submission with the United States that alleged Guatemala failed to enforce its labor laws with respect to collective bargaining and organization rights, freedom of association, and acceptable conditions of work. ${ }^{155}$ The United States issued a final report in which it sustained the allegations in the submission and requested a formal consultation. ${ }^{156}$ After the formal consultation was

151. See, e.g., Maria Sacchetti \& Perry Stein, 'We are America': DACA recipients, supporters say they are not going anywhere, WASH. POST (Sept. 5, 2017) [https://perma.cc/Z5UJ-BJKK] (describing DACA recipients' view of themselves as American).

152. TPP Full Text, supra note 101, at art. 19.5(1).

153. CAFTA-DR Final Text, Office of the United States Trade Representative, https://ustr.gov/trade-agreements/free-trade-agreements/cafta-dr-dominican-republic-central-america-fta/final-text [https://perma.cc/94HH-Z8UZ]. CAFTA-DR included some enforceable labor rights provisions:

labor laws means a Party's statutes or regulations, or provisions thereof, that are directly related to the following internationally recognized labor rights: (a) the right of association; (b) the right to organize and bargain collectively; (c) a prohibition on the use of any form of forced or compulsory labor; (d) a minimum age for the employment of children and the prohibition and elimination of the worst forms of child labor; and (e) acceptable conditions of work with respect to minimum wages, hours of work, and occupational safety and health.

Id. at art. 16.8. Unlike the NAALC or agreements negotiated under the 2015 Trade Promotion Act, it does not include anti-discrimination in employment provisions.

154. Lance Compa et al., Wrong Turn for Workers' Rights: The U.S.-Guatemala CAFTA Labor Arbitration Ruling - And What to Do About It (2018).

155. Id. at 3 .

156. Id. 
unsuccessful in resolving the dispute, the United States requested arbitration under the dispute settlement mechanisms of the agreement. ${ }^{157}$ Although the panel found that Guatemala had failed to effectively enforce its labor laws, it rejected the United States' claims, in part, because Guatemala's failure was not in a manner that affected trade between the parties. ${ }^{158}$

The United States had alleged that Guatemala's failure to enforce its laws affected trade because employers were able "to evade or forego ... costs associated with having a functioning union or a collective labor agreement in the workplace."159 It was the cost-savings that employers enjoyed in Guatemala that allowed them to gain a competitive advantage. ${ }^{160}$ The panel adopted a definition of "in a manner affecting trade between the Parties" that followed the United States' reasoning: "a failure to effectively enforce a Party's labor laws ... is 'in a manner affecting trade between the Parties' if it confers some competitive advantage on an employer or employers engaged in trade between the Parties." 161 Under that definition, the panel found the employers in Guatemala did not experience enough cost savings to have gained a competitive advantage. ${ }^{162}$

If future panels adopt the same definition, the United States likely does not violate the trade agreement when it fails to enforce the rights of noncitizen workers in industries that do not affect trade or development. ${ }^{163}$ At least $48 \%$ of unauthorized workers are employed in industries that likely

\footnotetext{
157. Id.

158. Id. at $16-17$.

159. Id. at 17 (alteration in original) (excerpting and annotating arbitral decision).

160. Id.

161. Id. at 11 .

162. Id. at 17-20. The panel did find that one employer may have gained a competitive advantage but determined that the United States had not presented enough evidence to support a finding that it was a sustained or recurring course of action. Id. at 21 .

163. The draft version of the USMCA includes clarifying language for the term. U.S.-Mex.-Can. Agreement Text, supra note 102, at art. $31 \mathrm{nn} .11,12$. Note 11 states the following, a "sustained or recurring course of action or inaction' is 'sustained' where the course of action or inaction occurs periodically or repeatedly and when the occurrences are related or the same in nature. A course of action or inaction does not include an isolated instance or case." Id. at art. 31, n. 11. Note 12 clarifies when the action or inaction is "in a manner affecting trade or investment between the Parties":
}

For greater certainty, a "course of action or inaction" is "in a manner affecting trade or investment between the Parties" where the course involves: (1) a person or industry that produces goods or provides services traded between the Parties or has investment in the territory of the Party that has failed to comply with this obligation; or (2) a person or industry that produces goods or provides services that compete in the territory of a Party with goods or services of another Party. 
do not affect trade - the service industry and construction; ${ }^{164}$ at least $18 \%$ of authorized immigrants work in jobs that likely do not affect trade or industry - retail and educational services. ${ }^{165}$ For workers in those kinds of industries, then, free trade agreements will not be as effective as a tool for specific enforcement of their workplace rights.

A third challenge is in the enforcement mechanism itself, and in the lack of enforcement mechanisms for the regulatory coherence measures. Free trade agreements seek cooperation between parties; as a result, much of the dispute resolution process is focused on voluntary compliance and cooperation. ${ }^{166}$ Indeed, as described above, parties must engage in consultation before engaging in the dispute settlement process. ${ }^{167}$ As the experience with the consultation process under the NAALC demonstrates, the process can take years. For example, the most recent submission against the United States took one year for Mexico to issue its initial report, and then another year and a half for the parties to consult and issue a joint declaration. ${ }^{168}$

If a complaining party needs dispute settlement to enforce the antidiscrimination provision against the United States, the process will result in even more time before the complaining party receives a resolution. First, under the TPP's dispute settlement provisions, the non-conforming party has several options to challenge the dispute settlement panel's determination of non-conformity. ${ }^{169}$ Further, a non-compliant party has a "reasonable period of time" in which to correct the non-conformity. ${ }^{170}$ This means that although the TPP has time limits set for the dispute settlement process - the Panel must issue its initial report within 150 days and its final report within thirty days of the initial report ${ }^{171}$ — the dispute settlement process has the potential to drag on much longer than the time limits would suggest. Accordingly, one challenge posed by the enforcement mechanisms is the length of time it will take to resolve any non-conformities with

\footnotetext{
164. Jeffrey S. Passel \& D’Vera Cohn, 2. Occupations of unauthorized immigrant workers, PEW RES. CTR. (Nov. 3, 2016), http://www.pewhispanic.org/2016/11/03/occupations-of-unauthorized-immigrant-workers/ [https://perma.cc/NG2T-4T6X].

165. Drew DeSilver, Immigrants don't make up a majority of workers in any U.S. Industry, PEW RES. CTR. (Mar. 16, 2017), http://pewrsr.ch/2n30g4n [https://perma.cc/39ZU-G7WJ].

166. TPP Full Text, supra note 101, at arts. 19.10-19.15, 28.2, 28.5-28.6.

167. See supra notes 136-39 and accompanying text.

168. Mex. NAO 2011-1, H2-B Visa Workers (2011), https://www.dol.gov/ilab/trade/agreements/naalc.htm [https://perma.cc/PH4T-9EU5] (type "h2" in search bar; then click on 2011Mexico Submission 2011-1 (H-2BVisa Workers)" entry).

169. TPP Full Text, supra note 101, at arts. 28.19-28.20.

170. Id. at art. 28.19(3).

171. Id. at art. 28.17(3)-28.18(1).
} 
the anti-discrimination provisions.

Similarly, the lack of enforcement mechanisms for the regulatory coherence measures could prove a challenge to effecting the anti-discrimination provisions. One of the primary criticisms of NAALC is that it does not subject most worker rights violation to fines or sanctions. ${ }^{172}$ Critics say that the lack of fines or sanctions mean that countries are less likely to engage in consultations in the first place. ${ }^{173}$ And critics argue that consultations themselves do not provide "a sufficient incentive to deter" countries from violating their own worker rights laws. ${ }^{174}$ Thus, voluntary cooperation alone may not be enough incentive for the United States to ensure regulatory cohesion with respect to its anti-discrimination laws. ${ }^{175}$

Finally, a shortcoming of trade agreements is that only governments are parties to the agreement, and so only governments are subject to sanctions or fines. ${ }^{176}$ This creates a misalignment in interests between governments and employers. ${ }^{177}$ Since governments bear the consequences of an employer's failure to comply with anti-discrimination provisions, employers lack an incentive to comply with the trade provisions. ${ }^{178}$

\section{B. Opportunities to Reinforce Noncitizen Workers' Rights}

Despite the challenges to enforcement, the non-discrimination provisions in trade agreements present an opportunity to reinforce noncitizen workers' rights in three ways. First, to fully comply with the agreements the United States will need to engage in more consistent enforcement of workplace rights. At the same time, the agreements will allow the United States to seek better enforcement of workplace laws across transnational jurisdictions. Second, the United States' trading partners will be motivated to ensure the United States complies with its obligations under the agreements. Accordingly, the United States will have additional incen-

172. Laura Okin Pomeroy, Note, The Labor Side Agreement Under the NAFTA: Analysis of its Failure to Include Strong Enforcement Provisions and Recommendations for Future Labor Agreements Negotiated with Developing Countries, 29 GEO. WASH. J. INT'L L. \& ECON. 769, 791-94 (1996).

173. Id. at 791-93.

174. Id. at 792

175. Of course, if the draft language allowing recourse to dispute settlement in the USMCA's Good Regulatory Practices chapter remains, then a party would be able to enforce the regulatory cohesion obligations against a party that engages in "a sustained and recurring course of action or inaction that is inconsistent with a provision of [the Good Regulatory Practices chapter]." U.S.-Mex.-Can. Agreement Draft Text, supra note 102, at art. 28.20(3).

176. Polaski, supra note 91, at 22-23.

177. Id. at 23 .

178. Id. 
tives to comply or face fines and sanctions. Finally, the agreements provide a tool for workers and their advocates to apply pressure to U.S. agencies to better enforce workplace rights and to organize campaigns that pressure employers to change discriminatory practices.

\section{Fill in Gaps in U.S. Agency Enforcement of Workplace Rights}

The anti-discrimination provisions in trade agreements provide an opportunity to fill in gaps in U.S. agency enforcement of workplace rights. The regulatory coherence and effective enforcement of labor laws provisions mean that to comply with the agreements, U.S. agencies need to better coordinate their enforcement of workplace rights and immigration law. The United States can file complaints against other member states when those states fail to enforce their labor laws, potentially filling in some of the jurisdictional gaps that U.S. agencies face when transnational companies or individuals are involved. Further, the provisions should encourage U.S. agencies, such as the EEOC, to take on cases involving noncitizen workers, providing better access to courts for those workers.

The United States' enforcement of its anti-discrimination laws with respect to noncitizen workers shows gaps in enforcement due to conflicting action by the agencies that enforce the laws. ${ }^{179}$ The anti-discrimination and regulatory coherence measures in trade agreement provide an opportunity for the United States to fill that gap in protection. As described above, trade agreements negotiated pursuant to the 2015 Trade Promotion authority must provide that a party effectively enforce its own labor laws. ${ }^{180}$ A violation must be through a "sustained or recurring course of action or inaction in a manner affecting trade or investment." 181 Similarly, parties should endeavor to achieve "regulatory coherence" in their domestic laws. ${ }^{182}$ Part of regulatory coherence is "prevent[ing] the creation of inconsistent requirements across agencies." 183

A submission under NAALC illustrates some of the results these provisions could achieve. The submittal complained that the United States failed to enforce its own labor laws-specifically, its existing minimum wage and overtime protections in workplaces employing noncitizens. ${ }^{184}$

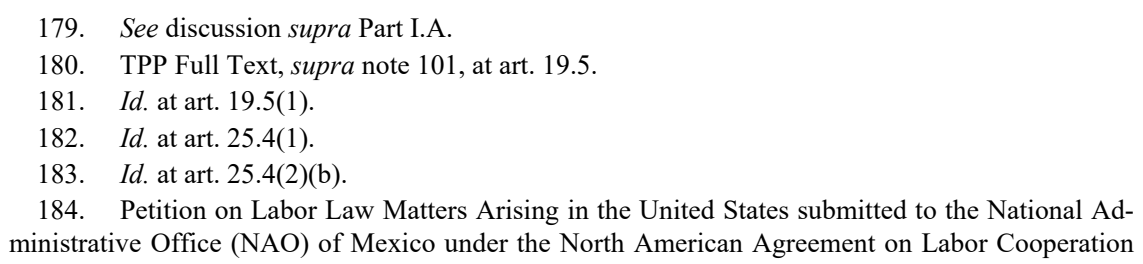


The submission attributed the failure to a Memorandum of Understanding between the U.S. Department of Labor (DOL) and the legacy Immigration and Naturalization Service (INS) that required the two agencies to share information and required the DOL to engage in enforcement procedures. ${ }^{185}$ Prior to Mexico considering the submission, DOL and INS revised the Memorandum of Understanding to ensure that immigration enforcement functions do not conflict with worker protection functions. ${ }^{186}$ Mexico issued a report and requested consultation under the NAALC. ${ }^{187}$ A joint declaration resulted in which Mexico and the United States agreed to collaborate on efforts to promote noncitizen workers' rights in the United States, and in which the DOL agreed to develop materials about noncitizen workers' rights. ${ }^{188}$ This case, then, is an example of how workers' rights provisions in a trade agreement can lead to increased regulatory cohesion in the enforcement of domestic labor laws - even in the absence of a robust enforcement mechanism in the trade agreement. The end result was reinforcement of noncitizens' workplace rights.

This example also shows why the United States should work on its efforts towards regulatory coherence because where there are enforcement mechanisms, the United States will face fines and sanctions for failing to effectively enforce its anti-discrimination laws. This could encourage federal agencies to engage in more efforts to collaborate between agencies. ${ }^{189}$

(NAALC), Mex. NAO 9804, at 1-5 (Sept. 17, 1998), https://www.dol.gov/ilab/submissions/ pdf/mx_9804_yale_submission.pdf [https://perma.cc/K8VN-F9Y4] [hereinafter 1998 NAALC Petition].

185. Id. at 3-5.

186. Mex. NAO 9804, Yale/INS (1998), U.S. DEP'T OF LABOR, https://www.dol.gov/ilab/ trade/agreements/naalc.htm [https://perma.cc/6X4T-F2NG] (type "Yale/INS" in search bar; then click "Mexico NAO Submission 9804 (Yale/INS)" entry).

187. Id.

188. Ministerial Consultations Joint Declaration Between the Department of Labor of the United States of America and the Secretariat of Labor and Social Welfare of the United Mexican States Concerning U.S. NAO Public Communications 9901 and 2000-01, and Mexican NAO Public Communication 9804, Mex. NAO 9804, (June 11, 2002), https://www.dol.gov/ilab/reports/pdf/ jointdeclar061102.htm [https://perma.cc/4GMB-T89S].

189. Although individual states in the United States are not considered a party to the United States' trade agreements and their laws are not considered U.S. domestic law under the agreements, federal workplace employment agencies should also consider establishing cooperative working groups with related state agencies. Some agencies already do this to a certain extent, but more cooperation could lead to better enforcement. For example, the EEOC cooperates with state fair employment agencies to coordinate enforcement of federal and state anti-discrimination in employment laws. EEOC, Fair Employment Practices Agencies (FEPAs) and Dual Filing (last visited Oct. 6, 2018), https://www.eeoc.gov/employees/fepa.cfm [https://perma.cc/C484-7HXE]. Trafficking task forces in various jurisdictions represent a type of cooperative model that involves local and federal law enforcement and non-governmental organizations. In some instances, such groups have been instrumental in achieving better enforcement of trafficking laws. Departments of Justice, Labor and Homeland Security Announce Phase II of Anti-Trafficking Coordination Team Initiative, U.S. DEP'T OF JUSTICE 
The United States already has a group of agencies working together on employment and labor issues - the Interagency Working Group for the Consistent Enforcement of Federal Labor, Employment and Immigration Laws. ${ }^{190}$ The group includes the EEOC, DOL, DHS, DOJ, and the National Labor Relations Board. ${ }^{191}$ Its purpose is to "promote effective enforcement of federal labor, employment, and immigration laws" and "to identify policies and procedures that promote the consistent enforcement of those laws and protect all workers in the U.S." 192 To help the United States better achieve regulatory coherence with respect to its obligations under trade agreements, the working group could add that to its regular agenda.

Relatedly, the Trade Policy Staff Committee and the Trade Policy Review Group does not include the EEOC. ${ }^{193}$ Now that eliminating discrimination in employment is one of the United States' trade goals, it would make sense to include the EEOC. The EEOC could provide expertise and knowledge to the committee. It could also help identify gaps in U.S. enforcement of employment discrimination laws and help achieve regulatory coherence.

Further, the submission process could lead U.S. agencies to exercise their prosecutorial discretion to protect rather than prosecute workers whose employers have subjected them to discrimination. When agencies conflict in their treatment of noncitizen workers, the agencies often are making different decisions about how to exercise their prosecutorial discretion. ${ }^{194}$ Looking to the Durrett Cheese case as an example, there, the DHS and DOJ made different prosecutorial decisions about whether the

(June 25, 2015), https://www.justice.gov/opa/pr/departments-justice-labor-and-homeland-securityannounce-phase-ii-anti-trafficking [https://perma.cc/33FB-GTW5] (describing successful partnerships with local law enforcement agencies and NGOs that led to an increased number of trafficking cases filed, and an increased number of defendants charged and prosecuted for trafficking crimes).

190. Fact Sheet: Establishment of Interagency Working Group for the Consistent Enforcement of Federal Labor, Employment and Immigration Laws, U.S. DEP'T OF LABOR, https://www.dol.gov/ general/immigration/interagency-working-group [https://perma.cc/74CW-P5FE] (last visited Oct. 6, 2018).

191. Id.

192. Id.

193. Executive Branch Agencies on the Trade Policy Staff Committee and the Trade Policy Review Group, OFFICE OF THE UNITED STATES TRADE REPRESENTATIVE, https://ustr.gov/about-us/executive-branch-agencies-trade-policy-staff-committee-and-trade-policy-review-group [https://perma.cc/M2BL-F9L4] (last visited Oct. 6, 2018).

194. Morrison, Executive Estoppel, supra note 1, at 323-28 (arguing that the structural limits of prosecutorial discretion, internal agency guidelines regarding prosecutorial discretion, and ethical guidelines all support the exercise of prosecutorial discretion to protect not prosecute unauthorized workers subjected to employer's violations of anti-discrimination and labor laws). 
workers were victims or perpetrators. ${ }^{195}$ On the one hand, DHS determined the workers were the victims of a crime and so exercised its discretion to not prosecute the workers, and instead sign off on a visa for the workers. ${ }^{196}$ On the other hand, DOJ determined the workers were the perpetrators of a crime and so exercised its prosecutorial discretion to criminally charge the workers. ${ }^{197}$

Although congressional intent, internal guidelines, and prosecutorial ethics suggest that the DOJ's decision to prosecute the workers was unwarranted, ${ }^{198}$ the United States' obligations in trade agreements could have provided additional reasons for the DOJ to exercise its prosecutorial discretion consistent with DHS's exercise of prosecutorial discretion. Workers and their advocates could point not only to existing protections under U.S. law, but also to the provisions in free trade agreements that require the United States to "ensure that persons with a recognised interest under its law ... have appropriate access to impartial and independent tribunals for the enforcement of [its] labour laws."199 When U.S. agencies fail to protect, and instead prosecute, workers when they complain about workplace discrimination, it denies those workers appropriate access to tribunals for the enforcement of the workers' right to be free from a discriminatory workplace. ${ }^{200}$ Thus, the provisions in the trade agreement could lead agencies to exercise favorably their prosecutorial discretion and better coordinate their treatment of noncitizen workers.

Trade agreements also provide an opportunity to fill-in gaps caused by jurisdictional issues. Where bad actors or recruiters abroad could escape liability, the United States could use the enforcement measures in trade agreements to achieve remedy. This would apply only in situations where the country in which the bad actor is located is a party to the agreement. The party would also have to fail to enforce its own labor laws in a manner that affects trade.

Using Global Horizons as an example, had a trade agreement existed between the United States and Thailand that included an anti-discrimination provision, the United States may have been able to demonstrate that Thailand violated it by allowing recruiters to operate in ways that violated

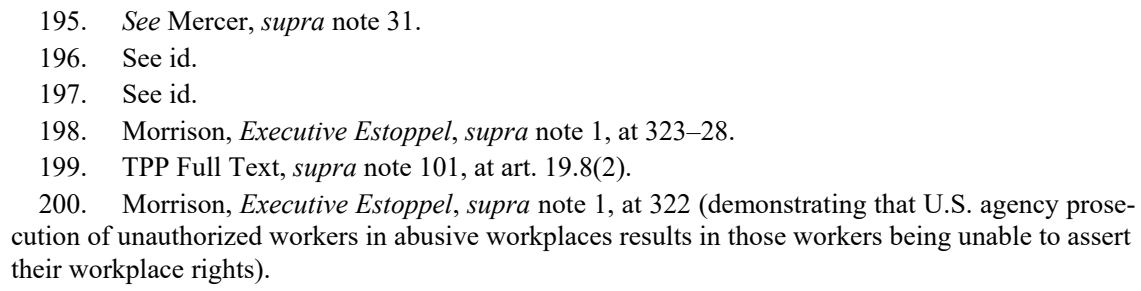


the anti-discrimination provisions of the free trade agreement. ${ }^{201}$ Although this would not benefit the workers directly, it provides an opportunity to reinforce migrant workers' rights and prevent future workers from being victimized by actors who otherwise would escape prosecution or liability.

The final gap that the labor provisions may help fill is that of access to courts for victims of discrimination. To the extent that effective enforcement of Title VII requires access to remedy in federal courts, barring noncitizen victims of discrimination from that access would violate the United States' obligation to effectively enforce its labor laws. ${ }^{202}$ As noted above, many victims of discrimination in the United States cannot get access to courts to enforce their rights. ${ }^{203}$

Bringing the United States into compliance with this provision could motivate Congress to pass legislation that address the barriers to access. It could also motivate federal agencies to seek remedy on behalf of victims of discrimination. For example, the EEOC could fill in this gap. The EEOC sets a five-year strategic enforcement plan in which it identifies priorities for enforcement. ${ }^{204}$ The EEOC could include as a priority the enforcement of systemic discrimination cases involving noncitizen workers in an industry that affects trade. And because the EEOC enjoys procedural and other advantages in litigation that private plaintiffs do not, ${ }^{205}$ it will not face the same challenges in accessing courts that this article described above. ${ }^{206}$

\section{Additional Incentives for the United States to Enforce Existing Worker Protections}

Trade agreements with an enforceable anti-discrimination provision also will incentivize U.S. agencies to enforce the rights of noncitizen workers. Kimberly A. Nolan García points out that "[s]tates may strive to protect labor rights not because they value them intrinsically, but because they are concerned with how labor rights violations may affect their trade

201. See supra notes 34-47 and accompanying text.

202. See Morrison, Executive Estoppel, supra note 1, at 303-11 (arguing that Title VII requires victims of discrimination have access to courts and remedy to be effective because it relies on the "private attorneys general" to enforce its provisions).

203. See discussion supra notes 50-55 and accompanying text.

204. U.S. EQUAL EMP. OpPORTUNity COMM'N, Strategic ENFORCEMENT Plan: Fiscal YEARS 2018-2022 (2018), https://www.eeoc.gov/eeoc/plan/strategic_plan_18-22.cfm [https://perma. cc/P7ZT-5BG2].

205. Morrison, EEOC as Fist, supra note 1, at 130-33, 144-48 (describing advantages the EEOC enjoys in bringing systemic/pattern or practice claims - namely, procedural advantages and its expertise and capacity in handling Title VII claims).

206. See supra notes 50-55 and accompanying text. 
relations with other nations." ${ }^{207}$ Additionally, the United States' trading partners have reason to enforce the United States' obligations, especially with respect to noncitizen workers, because of the comparative advantage the United States experiences in industries that employ noncitizens.

Free trade agreements negotiated pursuant to the 2015 trade promotion authority make the employment discrimination provisions subject to the same dispute settlement provisions as the other trade obligations. As a result, a trade agreement can provide additional incentives for the United States to enforce noncitizen workers' rights. Unlike the NAALC, agreements under the 2015 trade promotion authority subject the United States to trade sanctions or fines if the United States fails to effectively enforce its own anti-discrimination laws in a manner that affects trade or development. $^{208}$

Moreover, the United States' trade partners may see an advantage in bringing a complaint against the United States. Although some of the industries in which noncitizens work may not affect trade or development, ${ }^{209}$ many of the industries in which noncitizens work affect trade and development and are ones in which the United States enjoys a comparative trade advantage. Further, those industries are ones in which there have been many reports of worker abuse.

A comparative trade advantage exists when a country is able to more efficiently produce a good than another country. ${ }^{210}$ If the opportunity costs, "how much output of good Y must be forgone to produce one more unit of good X[,] . . . are different in each economy, then each country has a comparative advantage in the production of one of the goods." ${ }^{211} \mathrm{~A}$ country will experience a comparative advantage when it makes "intensive

207. Kimberly A. Nolan García, Transnational Advocates and Labor Rights Enforcement in the North American Free Trade Agreement, 53 LATIN AM. POL. \& SoC'Y 29, 36 (2011).

208. The TPP provides an example of what the dispute settlement process would look like. After parties engage in formal consultations, the complaining party may request that a panel hear the dispute under the dispute settlement provisions. TPP Full Text, supra note 101, at Ch. 28.7(1). The panel issues an initial report to which the parties may respond. Id. at art. 28.17(3)-(8). After the panel presents the initial report, the panel issues a final report and must release it to the public. Id. at art. 28.18(1)-(2). If the panel finds the party did not meet its obligations under the TPP, then the party must eliminate the non-conformity. See id. at art. 28.19. Where a party fails to eliminate the nonconformity, the complaining party may suspend benefits under the agreement. Id. at art. 28.20(2)-(3). The non-conforming party may elect to pay a fine if it cannot or will not eliminate the non-conformity. Id. at art. 28.20(10). Thus, under the TPP, the United States would face trade sanctions or fines if it failed to enforce the rights of noncitizen workers under federal anti-discrimination laws.

209. See supra notes 164-66 and accompanying text.

210. Wayne M. Morrison et Al., Cong. ReSEArCh SERV., RL33944, U.S. TRAde ConCEPTS, PERFORMANCE, AND POLICY: FAQS 1-2 (2015) (summarizing the nineteenth century economist, David Ricardo's, conceptualization of comparative advantage).

211. Id. at 1-2 (emphases omitted). 
use of the country's relatively abundant factor(s) of production." ${ }^{212}$ Those factors include "land, labor, physical capital (plant and equipment), human capital (skills and knowledge including entrepreneurial talent), and technology." 213 Governments can manipulate comparative advantage indirectly by "compensating for some form of market failure" not aimed at any particular industry or directly by promoting or using measures to protect specific industries. ${ }^{214}$

The United States enjoys a comparative advantage for many agricultural products under current free trade agreements. ${ }^{215}$ Among the products are soybeans, corn, tree nuts, cotton, pork, and poultry. ${ }^{216}$ Because of NAFTA, the United States enjoys a comparative advantage with Mexico for poultry products, pork products, apples, and pears. ${ }^{217}$ The advantage is driven, in part, by the United States' amount of arable land, the United States' transportation infrastructure, the United States' technology-including refrigeration capacity, and the United States' financial system. ${ }^{218}$

But an overlooked factor may be the agricultural and food manufacturing industry's use of noncitizen workers. Unauthorized workers represent $18 \%$ of agricultural workers and $13 \%$ of food manufacturing workers. ${ }^{219}$ Immigrant workers - workers who are noncitizen and authorizedmake up $15 \%$ of agricultural workers and $17 \%$ of food manufacturing workers. ${ }^{220}$ And as described above, many of the reports of abusive work environments involve precisely those industries. ${ }^{221}$

"[E]ach country can realize gains from trade by specializing in producing what it does relatively well and in which it has a comparative advantage and trading for what it does relatively less well and in which it has a comparative disadvantage." 222 To the extent that agricultural and food

\footnotetext{
212. Id. at 2 .

213. Id.

214. Id.

215. Office of the Chief Economist, U.S. Dep't of Agric., Trade Agreements and U.S. AGRICULTURE 2-3 (2014), https://www.usda.gov/oce/economics/papers/WhitePaper_012014_TradeAgreemeTra.pdf [https://perma.cc/D85R-77MS]; see also ForEIGN AGRIC. SERV., U.S. DEP'T OF Agric., Free Trade AgreEments AND U.S. AgRiculture 3-4 (2016), https://www.fas.usda.gov /sites/default/files/2016-06/2016-06_iatr_ftas.pdf [https://perma.cc/3Y8C-DLF8] (concluding U.S. exports are much more competitive in countries with which the United States has a trade agreement).

216. OFFICE OF THE CHIEF ECONOMIST, supra note 215, at 4.

217. Foreign AGRIC. SERV., supra note 215, at 2-3.

218. OFFICE OF THE CHIEF ECONOMIST, supra note 215.

219. DeSilver, supra note 165.

220. Id.

221. See supra notes 13-15.

222. MORRISON ET AL., supra note 210, at 2.
} 
manufacturing employers hire noncitizen workers to gain market advantages, the United States' failure to enforce the workplace rights may represent a direct intervention by the United States to manipulate its comparative advantage. As a result, the United States' trading partners would be likely to complain under a trade agreement, particularly where it creates a comparative disadvantage for the complaining country.

Finally, even though the United States has incentives under trade agreements to enforce its laws protecting noncitizen workers, the misalignment in interests between the United States and employers, described above, may pose an obstacle. ${ }^{223}$ Pass-through regulations could remedy that obstacle. ${ }^{224}$ The United States could enact pass-through regulations that fine employers whose workplace practices result in the United States receiving a fine under a trade agreement. ${ }^{225}$ In sum, trade agreements provide incentives for the United States to enforce its own anti-discrimination laws with respect to noncitizen workers and the ability to address any obstacles to its enforcement of those laws.

3. Create Political Pressure on U.S. Agencies to Enforce AntiDiscrimination Laws and a Source of Framing to Pressure Employers to Change Their Conduct

Enforceable anti-discrimination provisions in trade agreements also provide an opportunity to workers and their advocates. First, the public submission process provides a mechanism through which workers can put political pressure on U.S. agencies to better enforce noncitizen workers' right to be free from discrimination in the workplace. Second, the provisions provide an organizational tool for activists to frame noncitizens' workplace rights as human rights and respect for the rule of law. In this way, activists can change the narrative around noncitizen workers and place pressure on employers to change their behavior.

\section{a. Pressure on U.S. Agencies}

The public submission provisions provide an opportunity for non-governmental organizations to put pressure on United States agencies when they do not adequately enforce anti-discrimination laws, even where the violation does not result in dispute settlement and the attendant fines and

\footnotetext{
223. See supra notes 177-79 and accompanying text.

224. Polaski, supra note 91, at 23.

225. Id.
} 
sanctions. ${ }^{226}$ This can result not only in remedial action because the government desires to avoid potential fines or sanctions, but also in preventative action. ${ }^{227}$ Further, the submission process could lead U.S. agencies to exercise their prosecutorial discretion to protect rather than prosecute workers whose employers have subjected them to discrimination. Accordingly, when advocates effectively use the public submission process under free trade agreements, free trade agreements can lead to better protections for noncitizen workers, even in the absence of enforcement under the agreement.

The political scientist Jonathan Graubart looked at the use of the submittal process under NAALC and determined that despite the lack of strong enforcement mechanisms, activists were successful in achieving domestic political gain in the United States, Canada, and Mexico. ${ }^{228}$ For example, in 1998, a group of noncitizen workers in the Washington apple industry and their advocates filed a submission with Mexico that alleged that employers in the industry routinely violated noncitizen workers' rights with respect to freedom of association and organization, collective bargaining, non-discrimination, a workplace free of occupational injuries and illnesses, compensation for occupational injuries and illnesses, and protection of migrant workers. ${ }^{229}$ The workers argued the United States failed to enforce its workplace laws against the employers, and so violated its obligations under NAALC. ${ }^{230}$ Mexico issued a report and requested consultation. $^{231}$ The consultation resulted in an agreement by the Department of Labor to engage in outreach efforts to educate noncitizen workers about their workplace rights, and to host public information sessions that received comments from the public about how to better enforce the rights

226. Id at 24 (describing successful efforts on the part of NGOs who used the submission process under NAALC to draw attention to the plight of female workers in Mexican factories who faced pregnancy discrimination).

227. Id.

228. Jonathan Graubart, "Politicizing" a New Breed of "Legalized" Transnational Political Opportunity Structures: Labor Activists Uses of NAFTA's Citizen-Petition Mechanism, 26 BERKELEY J. EMP. \& LAB. L. 97, 132-37 (2005).

229. Apple Growers, Violations Of NAALC Labor Principles And Obligations In The Washington State Apple Industry Submission, Mex. NAO 9802, at 1 (n.d.) (unofficial translation), https://www.dol.gov/ilab/submissions/pdf/mx_9802_apple_growers_submissios.pdf [https://perma. cc/T7FY-6U6P]; see also Compa, supra note 49, at 235 (describing submission and process to bring attention to the submission).

230. Apple Growers, Violations Of NAALC Labor Principles And Obligations In The Washington State Apple Industry Submission, Mex. NAO 9802, at 1 (n.d.) (unofficial translation), https://www.dol.gov/ilab/submissions/pdf/mx_9802_apple_growers_submission.pdf [https://perma. cc/BRQ8-VG6D].

231. Mex. NAO 9802, Apple Growers, Report (Aug. 1999), https://www.dol.gov/ilab/reports/pdf/mx_9802_apple_growers_report.pdf [https://perma.cc/6BTD-D3AR]. 
of noncitizen workers. ${ }^{232}$ "On the ground, it led to improvements in housing conditions, piecework rate calculations, and health and safety enforcement." 233

Public submissions, then, can result in "information exchange and technical assistance" from the government, such as educational sessions or rights campaigns. ${ }^{234}$ This gives "leverage" to transnational groups and "compels states to accept the normative arguments presented by advocates and to commit to stronger labor rights enforcement."235

Graubart's study of NAALC's public submission process also showed that a complaint was more likely to result in "positive change" for workers when the recipient government directed political attention to the complaint, and the complaint was submitted by transnational organizations. ${ }^{236}$ This suggests that workers and their advocates should not only draw the recipient government's attention to the submission, but they also should reach out across borders to create the movement. Public submissions under trade agreements provide an opportunity for noncitizen workers to put political pressure on U.S. agencies to enforce their rights and to engage in measures to prevent employers from violating worker rights.

\section{b. Frame for a Social Movement to Pressure Employers}

Free trade agreements that incorporate workplace protections have the promise of creating a new narrative about noncitizen workers-one in which workers are human beings with fundamental human rights regardless of their immigration status. ${ }^{237}$ The inclusion of anti-discrimination provisions, means that trade agreements can become a frame to broaden the number of people who support workplace rights for noncitizen workers in the United States. ${ }^{238}$ The frame can, in turn, create vulnerabilities within

232. Mex. NAO 9802, Apple Growers, Ministerial Consultations - Mexico Submissions 9801, 9802 and 9803 (May 18, 2000), https://www.dol.gov/ilab/reports/pdf/minagreemt9801-98029803.htm [https://perma.cc/Y6MT-LQKS].

233. Compa, supra note 49, at 235.

234. Polaski, supra note 91 , at 24.

235. García, supra note 207.

236. InT'L LABOUR ORG., SOCIAL DimENSIONS OF FreE TRADE AGREEMENTS $49-50$ (2013) (citing García, supra note 207, at 29-60).

237. Cf. Lyon, supra note 65, at 495 (arguing that a ratification debate on the U.N. Convention on Migrant Worker Rights would "expos[e] more U.S. citizens to the notion that immigrant workers are the subject of a human rights treaty" and thus "help to shift the political climate toward policy reform").

238. Ruben J. Garcia, Transnationalism as a Social Movement Strategy: Institutions, Actors and International Labor Standards, 10 U.C. DAVIS J. INT'L L. \& POL'Y 1, 2-3 (2003) (“Frames provide a way to look at an issue that is intended to broaden the number of people who support the goals of a social movement."). 
the current, dominant narrative surrounding noncitizen workers, and create an opportunity to convert that narrative. With a new narrative, advocates can use public submissions and other tools to link specific employers to the systemic problem of exploiting noncitizen workers. ${ }^{239}$ Thus, even in the absence of real remedies or enforcement, advocates can harness the worker rights standards in trade agreements to build a social movement that results in pressure on companies that discriminate against employees. $^{240}$

There are two different types of framing for which free trade agreements could prove useful. The first type of frame has to do with how proponents of particular policies communicate the reason the public should support the policy. These are called value frames. A value frame "draws 'an association between a value and an issue that carries an evaluative implication: it presents one position on an issue as being right (and others wrong) by linking that position to a specific core value.",241 Proponents and opponents of a particular policy outcome may use the same value to frame the issue. ${ }^{242}$ A benefit of value framing is that it can "help to promote shared frames of reference for understanding issues." 243 The hope is that the shared frame of reference results in "more effective deliberation" about policy choices. ${ }^{244}$ The role that value framing has on public policy choices means that when social movement actors engage in the framing process, they must consider which values will most effectively "inspire and legitimate" their campaign. ${ }^{245}$

The second has to do with the process that social movement actors use to "inspire and legitimate [their] activities and campaigns." 246 In this respect, a frame is an "action-oriented set[] of beliefs and meanings." 247

239. See Tim Bartley \& Curtis Child, Shaming the Corporation: The Social Production of Targets and the Anti-Sweatshop Movement, 79 AM. SOC. REV. 653, 656 (2014) (describing how social movements identify targets for advocacy).

240. See, e.g., Weiss, supra note 11, at 507 (arguing advocates can use international labor standards "to induce corporate compliance with core international labor rights, even in the absence of strong national or local level enforcement.").

241. Paul R. Brewer \& Kimberly Gross, Values, Framing, and Citizens' Thoughts about Policy Issues: Effects on Content and Quantity, 26 POL. PsYCHOL. 929, 931 (2005) (quoting Paul R. Brewer, Value Words and Lizard Brains: Do Citizens Deliberate About Appeals to Their Core Values?, 22 POL. PSYCHOL. 45, 46 (2001)).

242. Id. at $930-31$.

243. Id. at 944 .

244. Id.

245. Robert D. Benford \& David A. Snow, Framing Processes and Social Movements: An Overview and Assessment, 26 ANN. Rev. Soc. 611, 614 (2000).

246. Id.

247. Id. 
Movement actors construct frames by identifying a situation in need of change and attribute blame (diagnostic framing), set out an alternative (prognostic framing), and "urge others to act in concert to affect change [motivational framing]." 248

Two potential value frames presented by free trade agreements are that of human rights and the rule of law. Scholars and advocates have looked to international human rights standards as a frame for arguing that noncitizen workers deserve workplace protections regardless of immigration status. ${ }^{249}$ For example, Lance Compa has argued that advocates should refer to international human rights when advocating for noncitizen workers. ${ }^{250}$ In particular, he maintains that advocates should look to UN and ILO conventions to "frame[] advocacy as a human rights mission, not defending 'illegal aliens." "251 But the United States has not ratified most of the ILO's worker rights conventions; it has only ratified the Abolition of Forced Labor Convention ${ }^{252}$ and the Worst Forms of Child Labor Convention. ${ }^{253}$ As Compa and others have noted, the United States is unlikely to ratify those conventions. ${ }^{254}$ In the absence of U.S. ratification of the ILO anti-discrimination convention, ${ }^{255}$ the inclusion of the anti-discrimination provisions in trade agreements can help to normalize the human rights expressed in the ILO conventions. ${ }^{256}$

The inclusion of workers' rights in free trade agreements also could draw an association between honoring noncitizen workers' rights and the



253. Worst Forms of Child Labour Convention, June 17, 1999, 2133 U.N.T.S. 161. Of course, as Beth Lyon has argued, noncitizen workers in the United States would be even better protected if the United States ratified the International Convention on the Protection of the Rights of All Migrant Workers and Members of their Families. See Lyon, supra note 65.

254. See Compa, supra note 49, at 219-21, 239-40 (summarizing the literature). Beth Lyon has noted that one of the barriers to achieving United States' ratification of the UN's Convention on Migrant Workers is that "any attempt to define immigrants as rights holders is a political non-starter." Lyon, supra note 65 , at 419.

255. Concerning Discrimination in Respect of Employment and Occupation Convention (No. 111), June 25, 1958, 362 U.N.T.S. 31.

256. Lance Compa also notes advocates" "creative use" of the submission process in NAALC to assert migrant worker protections as yielding "concrete positive results." Compa, supra note 49, at 234. Another advantage of including the ILO fundamental rights in trade agreements is that it avoids the lengthy process otherwise required for ratification of international conventions. For example, Beth Lyon describes a ten-step process for modern multi-lateral treaty making. Lyon, supra note 65, at 403-04 (citing Cong. Research Serv., 106Th Cong., Treaties and Other International AgreEments: The Role of THE United States SenAte: A Study PrePared For the CommitTeE on Foreign Relations, United States Senate 8-9 (Comm. Print 2001)). 
rule of law. First, that free trade agreements create an obligation on the part of the United States to effectively enforce its own labor laws, allows workers to call on the core value of respect for the rule of law to insist the United States reinforce their workplace rights. Second, that the provision is enforceable through both formal consultation and eventual resort to the dispute settlement process also taps into rule of law values because it legitimizes the enforcement of noncitizens workers' rights. Graubart has noted the role that even a quasi-judicial mechanism, such as the formal consultation process, has because it "incorporates the particular legitimating power of law in encouraging norm-based behavior." 257 A new frameone that emphasizes the human rights of noncitizen workers and the United States' obligation to enforce those rights - undermines the narrative that immigration restrictionists have created about noncitizen workers as a threat and criminal. ${ }^{258}$ Social scientists have found that this type of reframing of an issue can mitigate the effects of the initial frame. ${ }^{259}$ Thus, the anti-discrimination provisions in free trade agreements can provide a link between the core values of human rights and respect for the rule of law and the enforcement of noncitizens' workplace rights.

In turn, social movement actors can use the value frames to construct a movement that puts pressure on employers, especially multinational enterprises, to change their treatment of noncitizen workers. First, both rule of law and human rights provide a way for activists to engage in diagnostic framing. Advocates can point to employers' exploitation of the underenforcement of noncitizens' workplace rights as violating human rights and rule of law norms. ${ }^{260}$ Several non-governmental organizations in the United States have already explored and reported on the various ways that employers have violated noncitizen workers' workplace rights. ${ }^{261}$ Few

\footnotetext{
257. Graubart, supra note 228, at 103.

258. See discussion supra Part I.B.

259. Brewer \& Gross, supra note 241, at 931, 943.

260. Diagnostic framing often involves "injustice frames" whereby movements "identify the 'victims' of a given injustice and amplify their victimization." Benford \& Snow, supra note 245, at 615 .

261. See, e.g., Khokha, supra note 15 (describing sexual assault of female, noncitizen agricultural workers who lacking status were afraid to report); Frontline: Rape on the Night Shift, supra note 15 (reporting on workplace sexual assaults of female, noncitizen custodial workers); BAUER \& RAMíREZ, supra note 13, at 41-47 (summarizing interviews with noncitizen, female workers in the agricultural and meat processing industry). S. POVERTY L. CTR. \& AlA. APPLESEEd CNT. FOR LAW \& Justice, supra note 14 (describing results of surveys and interviews with workers in the Alabama Poultry Industry who reported receiving more dangerous and undesirable work assignments because of their national origin; workers also reported national origin harassment from coworkers). See also Rebecca Smith et al., Iced Out: How Immigration Enforcement Has Interfered with Workers' Rights, AFL-CIO 15-29 (2009), https://digitalcommons.ilr.cornell.edu/cgi/viewcontent.cgi?article=1020\&contexc=laborunions [https://perma.cc/TD6F-5FPW] (describing instances where workers reported workplace
} 
have looked explicitly at how that treatment violates human rights law and the rule of law. ${ }^{262}$ Using the anti-discrimination provisions in free trade agreements to illustrate both the human rights and rule of law frames, would provide the hook for activists to link specific employers to the problem.

Second, the worker rights provisions set out an alternative to the current, problematic treatment of noncitizen workers. This prognostic framing would allow social movement actors to show a different way of thinking about government enforcement of noncitizen rights-the nonenforcement is reframed as a threat to trade that undermines the rule of law, and the enforcement is reframed as necessary to upholding basic human rights values and respecting the rule of law. Finally, the worker rights provisions could also assist in activists' motivational framing of the issue. The enforceability of the provisions provides hope to activists that their collective efforts could result in change. ${ }^{263}$

Accordingly, the framing could change public opinion and, therefore, pressure employers to change their behavior. Social movements can address systemic problems, in part, because they "link[] particular actors to systemic problems" and draw attention to those actors through public information. ${ }^{264}$ Employers that are also multinational companies can make good targets for focused action because market- based concerns drive their decision-making and they can be more nimble in responding to social concerns than state actors. ${ }^{265}$ For example, multinational companies may seek "to preserve their reputations and maintain market positions in the face of globalizing markets." "266 As a result, over the last three decades, private actors have started to "incorporate[] international labor norms into private contracts and other instruments, such as industry codes of conduct, inter-

violations and then were put into removal proceedings by ICE); Workers on the Front Lines, POWER CAMPAIGN, http://thepoweract.org/worker-stories [https://perma.cc/WE45-E9EV] (last visited Oct. 9, 2018) (worker narratives describing workers who have been caught up in ICE raids of abusive employers and then placed in removal proceedings).

262. A recent report looked at the working conditions of casino and hotel workers in Las Vegas, Nevada and described how the working conditions did not comport with international human rights standards. FATMa E. MAROUf ET AL., BANKING ON UnSAFE Working CONDITIONS: Placing Profits BEFORE PROTECTION OF CASINO \& HOTEL WORKERS' HUMAN RightS IN DEUTSCHE BANK'S U.S. SUPPLY CHAIN (2016), https://www.law.uci.edu/academics/real-life-learning/clinics/pdfs/Bankingon-Unsafe-Working-Conditions-05-17-16.pdf [https://perma.cc/NFF3-JH9A].

263. Benford \& Snow, supra note 245, at 617 ("Motivational framing, the final core framing task, provides a 'call to arms' or rationale for engaging in ameliorative collective action ....").

264. Bartley \& Child, supra note 239.

265. Tim Bartley, Institutional Emergence in an Era of Globalization: The Rise of Transnational Private Regulation of Labor and Environmental Conditions, 113 AM. J. SoC. 297, 298-99 (2007).

266. Id. 
national framework collective agreements, and corporate social responsibility measures." 267 Thus, to the extent that free trade agreements prove a useful tool in reframing the negative narrative about noncitizens and framing social movements that promote workers' rights, they will also prove a useful tool to pressure companies to change their behavior.

\section{CONCLUSION}

Employer exploitation of noncitizen workers remains a persistent problem. U.S. agencies treat workers inconsistently based on the workers' transnational status, resulting in gaps in enforcement. Similarly, bad actors may escape prosecution for engaging in workplace abuses because they are outside of the United States' jurisdiction. And victims of systemic discrimination have increasingly experienced a lack of access to courts to enforce their rights.

This article has explored the ways in which labor protections in free trade agreements can solve some of those persistent problems and reinforce the rights of noncitizen workers. Because trade promotion authority and free trade agreements have included the elimination of employment discrimination and the promotion of regulatory coherence among their measures, free trade agreements provide three main opportunities to noncitizen workers.

First, the provisions can fill in gaps in U.S. enforcement of workplace provisions for noncitizen workers. To comply with the trade agreements, U.S. agencies need to work together to consistently enforce noncitizens' employment rights. The provisions also provide a way for agencies to reach bad actors who would otherwise be outside of the agencies' jurisdiction. Second, the United States has additional incentives to enforce antidiscrimination laws because it could face fines or sanctions under trade agreements, if it does not.

Finally, the employment provisions in free trade agreements are an additional source of pressure for advocacy campaigns. Through the public submission process, advocates can use free trade agreements to pressure U.S. agencies to enforce workers' rights, even in the absence of real enforcement under the trade agreement. Workers can also use free trade agreements as an organizational tool to frame a social movement that recognizes workers as having independent human rights, and that recognizes the enforcement of those rights as respect for the rule of law.

267. Weiss, supra note 11 , at 500 . 